M. D. Frisbee, et al. Processes leading to the re-activation of a sinkhole in buried karst and the subsequent drying of waterfalls in a small catchment located in northern Indiana, USA. Journal of Cave and Karst Studies, v. 81, no. 2, p. 69-83. DOI:10.4311/2017ES0116

\title{
PROCESSES LEADING TO THE RE-ACTIVATION OF A SINKHOLE IN BURIED KARST AND THE SUBSEQUENT DRYING OF WATERFALLS IN A SMALL CATCHMENT LOCATED IN NORTHERN INDIANA, USA
}

\author{
Marty D. Frisbee ${ }^{1, C}$, Zachary P. Meyers ${ }^{1}$, Jordyn B. Miller ${ }^{1}$, Carolyn L. Gleason ${ }^{1}$, Noah S. Stewart- \\ Maddox $^{1,2}$, Erik B. Larson ${ }^{3}$, Darryl E. Granger ${ }^{1}$, Siddharth Saksena ${ }^{4}$, Sayan Dey ${ }^{4}$, and Emily E. \\ Frisbee ${ }^{5}$
}

\begin{abstract}
A sinking stream pirated water from a series of waterfalls in a small catchment underlain by buried karst in northern Indiana after a sinkhole was scoured and enlarged over the course of 2016. The catchment has historical significance to Indiana, and the current landowners wish to restore flow to the waterfalls. We address the following questions: 1) where does the water go once it enters the sinking stream, 2) what transport processes are active in the carbonate rocks, and 3) what processes led to the re-activation of a buried sinkhole? Breakthrough curves (BTCs) of salt-slug tracer tests show that $24.6 \%$ of the chloride mass was recovered at a conduit spring (Spring 1), located $150 \mathrm{~m}$ from the sinking stream, and $26.6 \%$ of chloride mass was recovered at two diffuse springs (Springs 2 and 3 ), located $315 \mathrm{~m}$ from the sinking stream. Despite the difference in distances from the sinking stream, the salt-slug appeared in all springs in approximately two hours. The BTC for Spring 1 was single-peaked, consistent with advection through a single conduit, while the BTCs of Springs 2 and 3 were double-peaked and consistent with advection along bifurcated flowpaths. Spring 2 exhibited a long tail consistent with anastomosing flowpaths and/or presence of pooling along the flowpaths. The sinking stream and other inactive sinkholes are upstream of a dam built in the 1960s. Ponding conditions likely increased the hydraulic head over the buried karst and began dislodging sediment from open pores/conduits in the karst. Record rainfall and widespread flooding during the summer of 2015 scoured the pores leading to the enlargement and reactivation of the sinking stream by the fall of 2016.
\end{abstract}

\section{Introduction}

Hydrogeological processes in karst have been relatively well-studied in carbonate rocks of unglaciated southern Indiana (Murdock and Powell, 1967; Bassett, 1974; Bayless et al., 1994; Duwelius et al., 1996; Lee and Krothe, 2001; Zhou et al., 2002; Florea et al., 2018). However, these processes remain poorly quantified in glaciated northern Indiana. While much of Indiana is underlain by sequences of limestone and dolostone (Gray, 2000; Bedrock Geology of Indiana), it is more common to find carbonate rocks outcropping at the land-surface of southern Indiana in areas that were never glaciated. In comparison, carbonate rocks are typically buried under 30 to $120 \mathrm{~m}$ of glacial till in northern Indiana, and these rocks are only exposed at the land-surface, where erosion has uncovered them or streams have incised them (Casey, 1997; Gray, 2000; Hasenmueller and Packman). Bugliosi (1997), Casey (1997), and Eberts and George (1997) mentioned the presence of paleokarst (buried karst) in their studies of the hydrogeological and hydrogeochemical properties of the regional, carbonate aquifer that extends through northern Indiana, Ohio, and Illinois; they did not discuss the potential re-activation of buried karst features. Ultimately, our knowledge of groundwater/surface-water interactions that are facilitated by karst flowpaths and conduits in northern Indiana, Ohio, and Illinois is limited (Sasowsky et al., 2003; Torres and Bair, 2012).

Likewise, our hydrogeochemical understanding of the aquifers' susceptibility to contamination is limited. Groundwater can flow quickly and over long distances through carbonate rock aquifers; for example, groundwater traveled $9.5 \mathrm{~km}$ in just 25 hours in carbonate rocks in the Lost River karst basin located in Orange County, southern Indiana (Murdock and Powell, 1967). If groundwater velocities of this same magnitude are present in northern Indiana, where row-crop agriculture is widespread (Randall and Mulla, 2001; Pyron and Neumann, 2008), then it has important implications for the transport of nutrients into the carbonate aquifers and subsequent impacts to freshwater ecosystems (Karr et al., 1985). Sinkholes provide a direct pathway for contaminants to enter a carbonate aquifer (Hallberg and Hoyer, 1982; Wiersma et al., 1986; Field, 1992; Panno et al., 1996, 2001; Herczeg et al., 1997; Florea and Wicks, 2001; Dussart-Baptista et al., 2003; Panno and Kelly, 2004; Lindsey et al., 2010). Consequently, karst aquifers in agricultural landscapes

\footnotetext{
${ }^{1}$ Department of Earth, Atmospheric, and Planetary Sciences, Purdue University, 550 Stadium Mall Drive, West Lafayette, IN 47907

${ }^{2}$ Idaho Water Resources Research Institute, 322 East Front Street, Suite 242, Boise, ID 83702

${ }^{3}$ Department of Natural Sciences, Shawnee State University, 940 Second St, Portsmouth, OH 45662

${ }^{4}$ Department of Civil Engineering, Purdue University, 550 Stadium Mall Drive, West Lafayette, IN 47907

${ }^{5}$ Wood PLC, 115 W Abeyta Street, Suite A, Socorro, NM 87801

cCorresponding Author: mdfrisbee@purdue.edu
} 
are particularly susceptible to pathogens such as fecal coliform (Ryan and Meiman, 1996; Reed et al., 2011) and nutrients such as nitrate (Panno and Kelly, 2004; Pronk et al., 2006; Long et al., 2008; Lindsey et al., 2010; Florea, 2019).

Sinkholes and sinking streams are common in southern Indiana (Bassett and Ruhe, 1974; Sinkhole Areas and Sinking-Stream Basins, 1997; Powell, 2002; Florea et al., 2018). In comparison, buried karst (Bosák et al., 1989; Zötl, 1989) is present in northern Indiana, where the open pores and conduits in the surface of the pre-existing carbonate rocks were covered and filled with glacial sediment during the Last Glacial Maximum. Buried karst features, plugged with low-permeability glacial till, may act as a barrier to downward vertical flow (Veress, 2016). However, there is no guarantee that these features will remain plugged (Armstrong and Osborne, 2003); Ford (1995) presents several scenarios through which descending water and ascending water can exhume and re-activate karst conduits. Once the sediment is removed, the conduit re-activates and impacts the hydrological behavior of the landscape around it. Thus, it is critical that we quantify how these buried karst features are re-activated and, once re-activated, how they impact the transport of water and contaminants from the land surface to the carbonate aquifer.

Here, we reconstruct and quantify the processes leading to the activation of a sinking stream in buried karst and the subsequent drying of waterfalls in a small, tributary catchment to the Wabash River (Figs. 1 and 2). This stream flows through a scenic, limestone canyon containing a series of four waterfalls (Fig. 2). The catchment, known locally as Fitch's Glen, has historical significance in Indiana, and the current landowners were interested in determining why the waterfalls dried up during 2016. A noticeable decrease in streamflow, in the catchment, was observed after the summer of 2015. This seemed strange since widespread flooding occurred in northern Indiana, following record rainfall in June

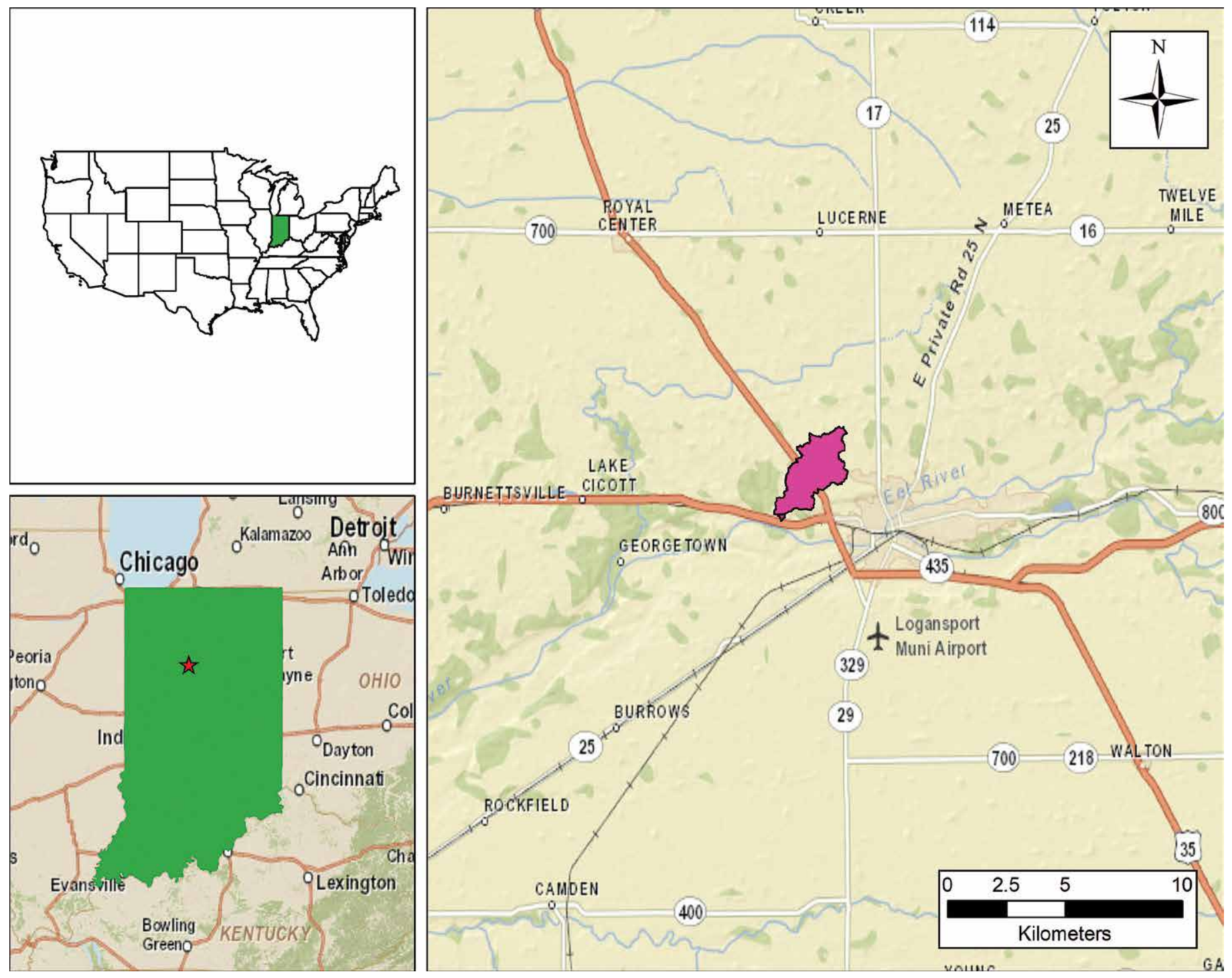

Figure 1. The national basemap is shown in upper left, the state basemap is shown in lower left, and the regional basemap is shown in the larger image on the right. The location of the Fitch's Glen catchment is shown by the magenta-colored polygon outlining the catchment boundary. 


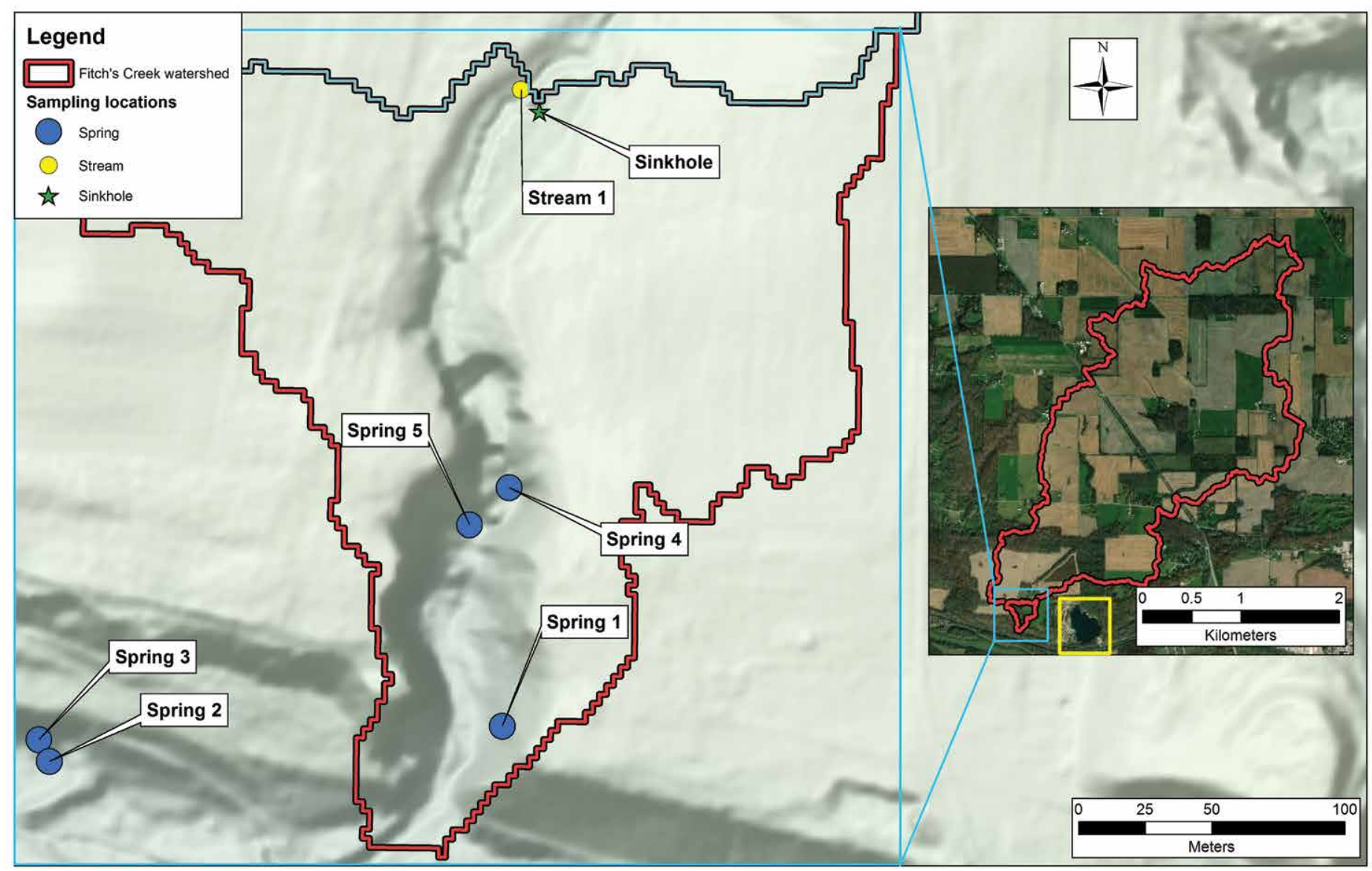

Figure 2. The image on the left is a LIDAR map ( $1 \mathrm{~m}$ resolution) showing locations of the sampling sites and sinking stream; the image on the right shows the boundary of the larger catchment, in red, and surrounding agricultural fields, which drain to this catchment. Please note: the quarry and lake that are mentioned in this article are outlined by the yellow box located to the left of the scale bar in the inset image.

and July of 2015 (Fig. 3). By the spring of 2016, the landowners noticed that a small sinkhole, upstream of the waterfalls, was diverting a small portion of streamflow. In early fall 2016 the sinkhole had developed into a large, sinking stream, and it had captured the entire stream, drying up the downstream waterfalls in the process.

We address these questions: 1) how did the sinking stream become re-activated in the buried karst; 2) where does the streamflow go once it enters the sinking stream; and 3) what transport processes are active in the carbonate rocks at Fitch's Glen? To address these questions, we used a combination of dye- and salt-tracing techniques, major element geochemistry of streams and springs, stable isotopes, and transport models to determine flow and transport parameters in the carbonate bedrock. Using this data, we traced recharge from the sinking stream to down-gradient springs, interpreted the breakthrough curves (BTCs), and addressed the implications of sinkhole development on nutrient loading into groundwater and other surface-water systems with particular reference to northern Indiana.

\section{Materials and Methods}

\section{Historical Setting}

The Fitch's Glen catchment is located 5.6 km west of Logansport, Indiana (16T $548674 \mathrm{mE}, 4511822 \mathrm{mN}$; Fig. 1). Historically, the catchment has been considered the most picturesque place in Cass County (Powell, 1913) due to the deep, limestone canyon and series of small, 1.2 to $3.1 \mathrm{~m}$, beautiful waterfalls on the property, especially since waterfalls are a rare feature on the till plains of northern Indiana. The property also has historical significance because it was the former home of Graham Fitch, a senator in Indiana from 1857-1861 and a brigade commander in the Union Army during the American Civil War. In addition, the site contains remnants of the old Wabash and Erie Canal constructed in the early 1800s. Fitch's Glen served as a trading post due to its proximity to the Wabash Canal and nearby grain warehouses, and the stream was used in the mid-1800s to supply hydropower to industrial mills (Powell, 1913). In the 1960s, a dam was built approximately $60 \mathrm{~m}$ downstream from the current sinking stream. The dam was later breached by private landowners, allowing the stream to freely flow through the catchment. 

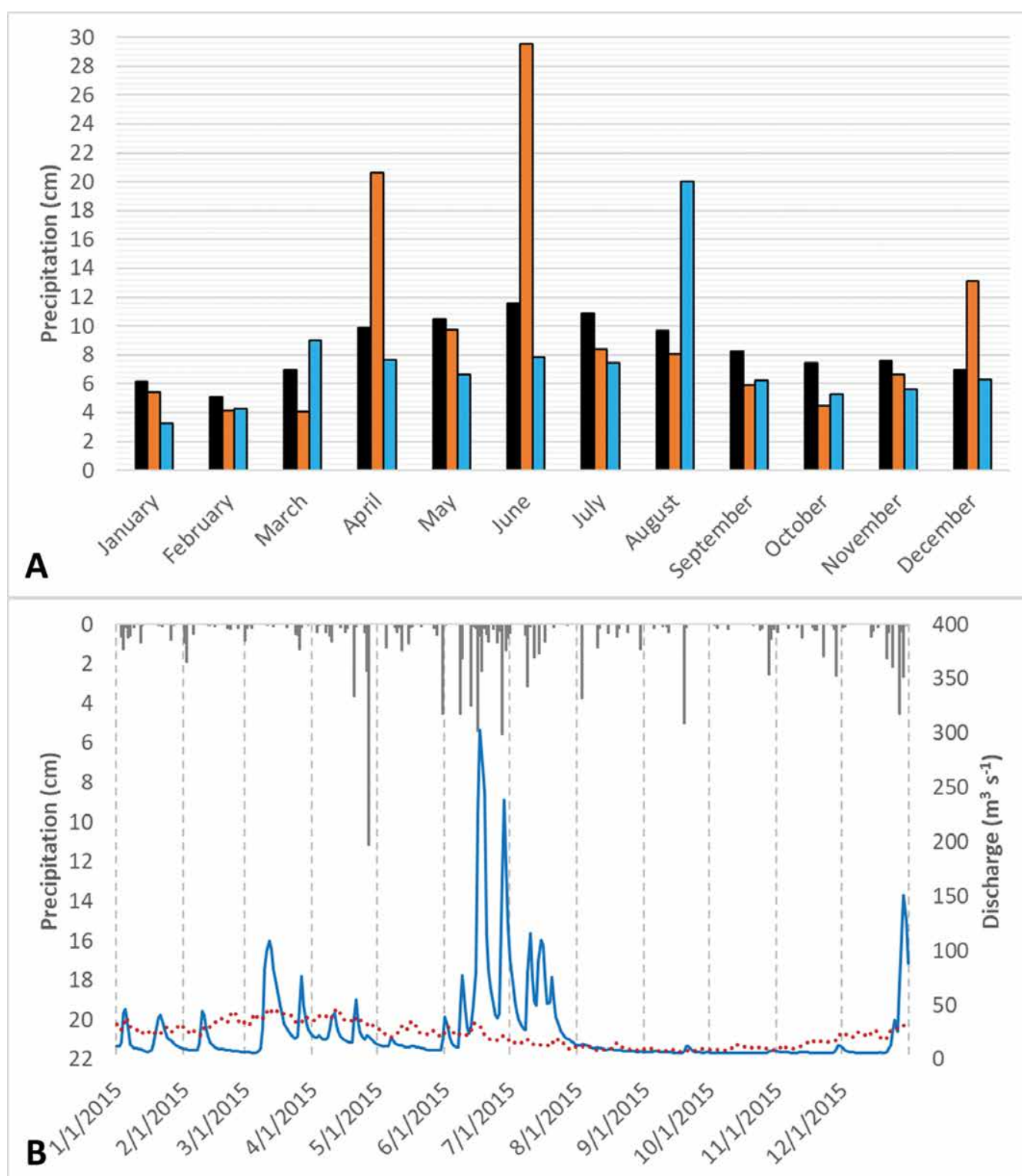

Figure 3. A) Plot showing monthly precipitation. Black bars represent the monthly precipitation averaged over the last 70 years (1947 to 2016), orange bars show monthly precipitation in 2015, and blue bars show monthly precipitation in 2016; and B) Combined hyetograph for Logansport, Ind., of a meteorological station located $3.1 \mathrm{~km}$ east of the Fitch's Glen catchment, and hydrograph for Eel River, a river located $13.6 \mathrm{~km}$ to the east of the catchment. The average daily discharge (measured from 1944 to 2016) is shown by the dotted red line, and the daily discharge for 2015 is shown by the solid blue line. The data was sourced from USGS Site 03328500; https://waterdata.usgs.gov/in/nwis/ inventory/?site no $=03328500$. The hyetograph shows daily precipitation in 2015 , and the data was sourced from NOAA Site LOGANSPORT CICOTT ST., IN US (https://www.ncdc.noaa.gov/cdo-web/ datasets/GHCND/stations/GHCND:USC00125117/detail).

in the lower reaches of the catchment.

Outwash and loamy till can be found on top of the bedrock, deposited by the Huron-Erie lobe during the Wisconsinan glaciation (Pinsak and Shaver, 1964). Glacial sediment also filled at least some of the conduits in the Wabash Formation, leading to the formation of buried karst. Locally, the stream, at the point of capture, flows across recent lake deposits that accumulated after construction of a small dam in the 1960s. Beneath the lake sediment is a thin, discontinuous layer of clay-rich sediment that appears to be glacial till.

\section{Climate and Hydrogeological Setting}

The average low and high January (winter) temperatures near Fitch's Glen are $-8.8^{\circ} \mathrm{C}$ and $0.3^{\circ} \mathrm{C}$, respectively, and average low and high July (summer) temperatures are $17.2^{\circ} \mathrm{C}$ and $28.7^{\circ} \mathrm{C}$ (NOAA Climate Data Online). Logansport receives an average of $101 \mathrm{~cm}$ of precipitation per year, and $40 \mathrm{~cm}$ of that occurs as snow from late October to late March

\section{Geological Setting}

Fitch's Glen is developed in the Silurian Wabash Formation, which is composed of a variety of limestone to dolostone facies (Pinsak and Shaver, 1964). It is widespread regionally and outcrops in the lower $0.05 \mathrm{~km}^{2}$ of the catchment. (Information on the Wabash Formation: Niagaran and Cayugan Series, Silurian System can be found at https://igs.indiana.edu/compendium/comp8qlg.cfm). At the surface, the rocks are massive, finegrained, light gray, heavily weathered and vertically fractured (Fig. 4A). Vertical shafts (Fig. 4B) and conduits (Figs. 4A, B) are present in the canyon walls. Shafts cut through the fine-grained, weathered rock facies, and appear to have routed flow to the large conduits along a silty friable, tan-colored facies (Figs. 4A, B). A thick, nodular facies is present beneath the silty facies and overlies a planar-bedded facies; the contact between the nodular and planar-bedded facies is exposed near the outlet of the canyon. Planar-bedded, fine-grained limestone is present near the middle and lower waterfalls and springs (Fig. 4C); the waterfalls likely formed from knickpoints occurring in this unit. Large boulders, coated with thick, tufa deposits and extensive tufa accumulation on the waterfalls, are present 


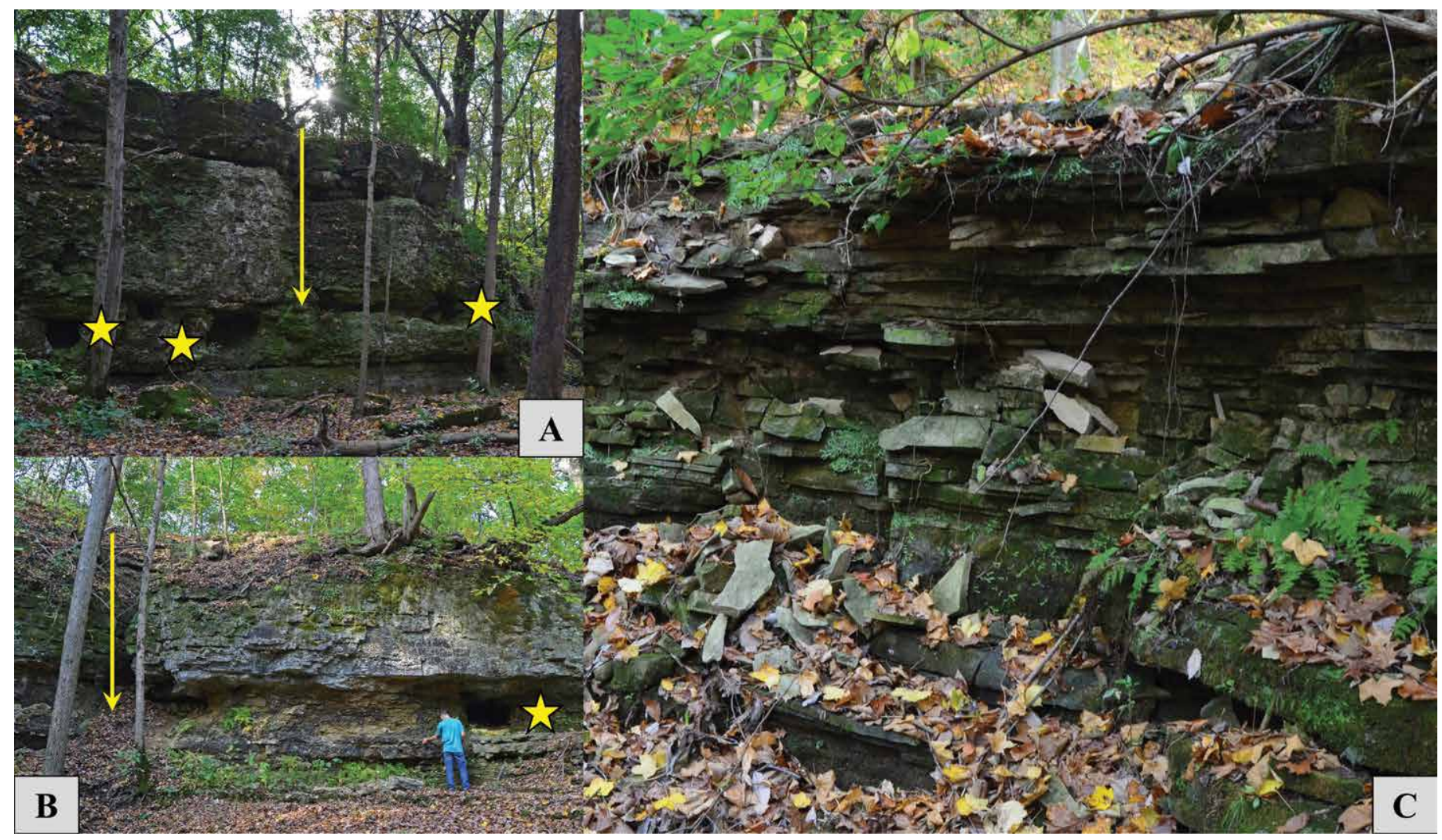

Figure 4. A) Photo showing the surficial massive, nodular limestone. The large conduit on the far left has a diameter of approximately 0.91 $\mathrm{m}$; B) Photo showing the silty, friable layer. The student co-author, wearing a blue shirt in the background, is $1.85 \mathrm{~m}$ tall for reference; and C) Photo showing the fine-grained, planar-bedded limestone. The outcrop shown in this photo forms a waterfall, which is approximately $1.52 \mathrm{~m}$. Stars show locations of large conduits and arrows show inferred shafts.

(Fig. 3A). Usually, Logansport receives $33 \mathrm{~cm}$ of rainfall from May through July. However, northern Indiana received 49 $\mathrm{cm}$ of rainfall during this period in 2015 , which resulted in regionally widespread flooding. The Fitch's Glen catchment is ungauged. Yet, meteorological data for Logansport, Ind. (5 km from the study site) and discharge data for the Eel River, located $5.3 \mathrm{~km}$ from the catchment, illustrate the magnitude of the flooding event in 2015 (Fig. 3B).

The larger catchment has a total drainage of $6.2 \mathrm{~km}^{2}(620 \mathrm{ha})$. A spring-fed stream drains the larger catchment and has incised a narrow canyon with steep walls with over $30 \mathrm{~m}$ of local relief in the lower $0.05 \mathrm{~km}^{2}$ ( $5 \mathrm{ha}$ ) of the catchment known as Fitch's Glen. Waterfalls are located in the glen (Fig. 2). The stream passes through low-relief agricultural fields before reaching the canyon and ultimately drains into the Wabash River. Google Earth imagery shows that: 1) the stream capture may have been present as early as 1998 (Fig. 5A); 2) stream capture was occurring by 2005 (Fig. 5B); and 3) the captured stream channel was almost as large as the main channel by 2012 (Fig. 5C). Readers are encouraged to view the Google Earth imagery at location $16 \mathrm{~T} 548685 \mathrm{mE}, 4512067 \mathrm{mN}$. However, the landowners state that the stream was not completely captured by the sinking stream before early 2015 , since the waterfalls were functioning at that time.

\section{Chronology of Site Visits}

The first trip to the site was made on March 25, 2016 to investigate the sinkhole (Fig. 6), identify potential discharge locations downgradient of the sinkhole, and propose future tracing experiments to quantify discharge locations and transport parameters. Five possible discharge points in the catchment were identified, including one conduit spring with a discrete emergence (Spring 1), two springs with diffuse emergences (Springs 2 and 3), and two springs discharging directly to the streambed (Springs 4 and 5; Fig. 7). Spring 1 emerges from a $1 \mathrm{~m}$ high by $1 \mathrm{~m}$ wide conduit in the planar-bedded limestone facies of the canyon wall, $150 \mathrm{~m}$ downstream from the sinking stream (Spring 1; Figs. 2, 7A). Water from this spring flows into the main stream channel providing almost all of the perennial flow to the lower reaches of the catchment. Springs 2 and 3 are located to the west of the mouth of the glen and provide flow to a small tributary that drains into the main stream. Approximately $500 \mathrm{~m}$ upstream of Spring 1, Springs 4 and 5 are located between a set of waterfalls. These two springs emerge in the streambed and discharge sufficient water to create localized mounding conditions in the stream. 


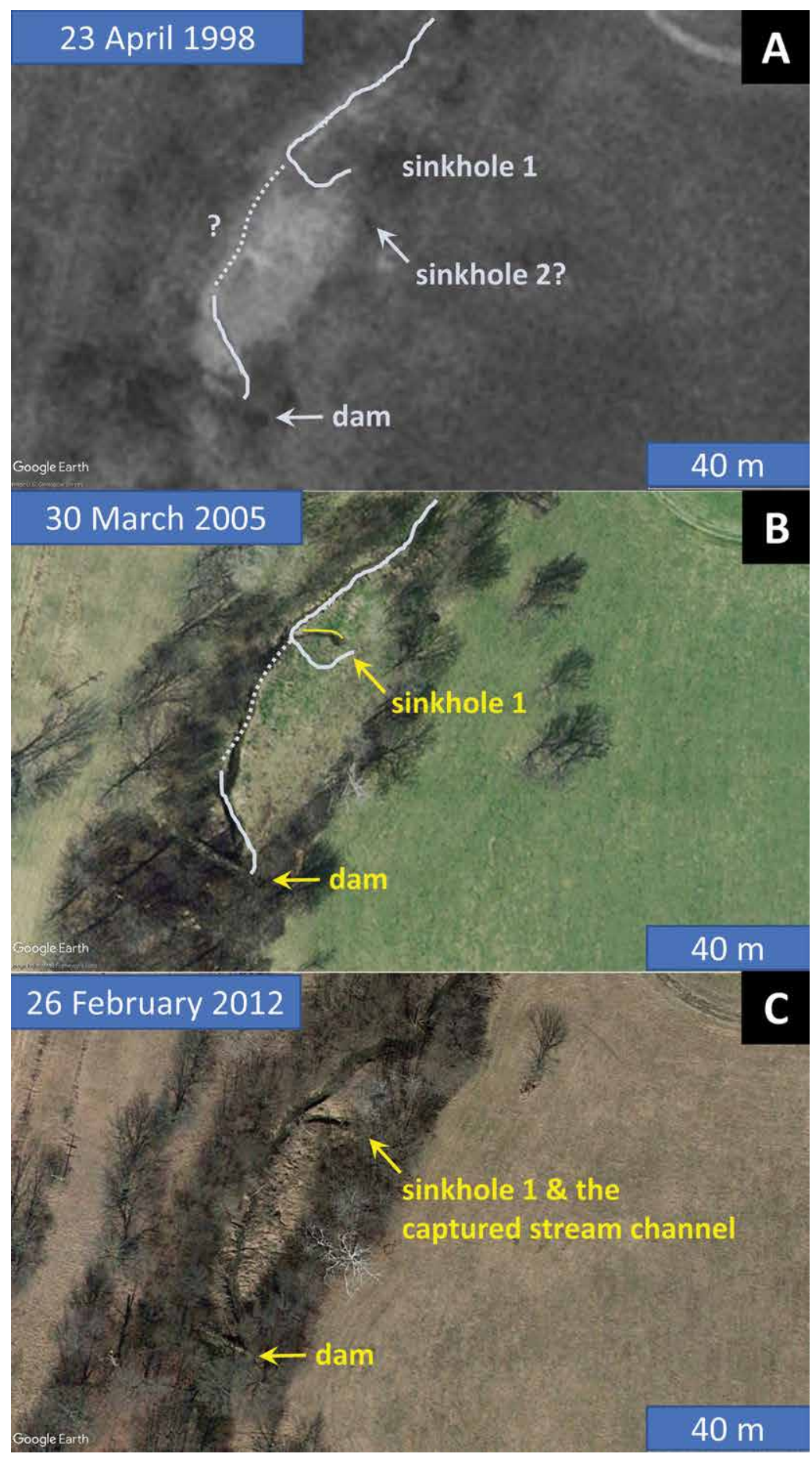

Figure 5. Google Earth imagery showing: A) the location of two possible sinkholes in 1998 (note that the main stream channel does not appear to be present or continuous to the dam(Source: Map data: Google Imagery @ 2018, DigitalGlobe, Image U.S. Geological Survey); B) the location of the sinkhole and initiation of stream capture by 2005 , indicated by the yellow line (note that the main stream channel is now present and continuous to the dam (Source: Map data: Google Imagery @ 2018, DigitalGlobe, Image IndianaMap Framework Data); and C) presence of ongoing stream capture in 2012 (Source: Map data: Google Imagery @ 2018, DigitalGlobe, Images IndianaMap Framework Data). The blue bar represents $40 \mathrm{~m}$ of distance. Images are oriented such that north is located at the top of each image. at Springs 1, 2 and 3 because dye breakthrough was observed at these springs during the second visit. Team mem-
The second trip to the site was made on October 29, 2016 to conduct a dye-tracing experiment for visual confirmation of the connection between the sinkhole and proposed discharge sites identified in the first trip. By October 2016, the sinkhole had greatly enlarged, and the entire stream was being diverted into the sinking stream (Fig. 6). The stream channel between the sinking stream and Spring 1 was completely dry, and the waterfalls were dewatered. Spring 1, therefore, supplied all of the water for streamflow downstream of the waterfalls until its confluence with a small tributary fed by Springs 2 and 3 (Figs. 2, 7B, and 7C). Springs 4 and 5, located between two waterfalls, were also dry. The dye-trace was successful; dye was observed at Springs 1, 2, and 3. However, the salt-trace was not successful due to equipment failure. Therefore, the salt-tracing results from the second trip are not reported.

The third trip was made on November 11, 2016. During this visit, a combined salt- and dye-tracing experiment was conducted on the sinking stream, water samples were collected from the stream and springs, and discharge was measured at each spring and in the stream, upstream of the sinking stream. The dye-trace and salt-trace were successful. During this trip, the researchers also measured the physical dimensions of the swallow and the sediment thickness overlying the carbonate rock near the hole. The opening of the sinking stream is roughly triangular, with an area of $1.9 \mathrm{~m}^{2}$ and is $2 \mathrm{~m}$ deep, relative to the land-surface (Fig. 6B). There is approximately $1.2 \mathrm{~m}$ of sediment deposited on top of the carbonate rocks near the sinkhole. A thin 8- to $10 \mathrm{~cm}$ layer of clay is present at the bottom of the sediment and on top of the carbonate rocks.

\section{Salt- and Dye-Tracing Methods}

We used salt- and dye-tracing methods to directly quantify flow (Greene, 1997) and transport parameters of the conduits and fractures (Benischke et al., 2007) in the catchment. Solinst Model 3001 LTC Junior LTC leveloggers were placed at Springs 1,2 and 3. The background SpC of the stream uphill of the swallow was measured to be $746 \mathrm{mS} \mathrm{cm}^{-1}$. Approximately $4.32 \mathrm{~kg}$ of salt was measured in a large, graduated cylinder and then dissolved in a $19 \mathrm{~L}$ bucket filled with stream water, creating a salt-slug with a SpC of 255,940 $\mathrm{mS} \mathrm{cm} \mathrm{cm}^{-1}$. Approximately $300 \mathrm{~mL}$ of Bright Dyes Fluorescent Industrial Red liquid dye was added to the salt-slug to provide a visible indicator of saltslug breakthrough at observed discharge points
hnical Data Bulletin. Team members were stationed e 


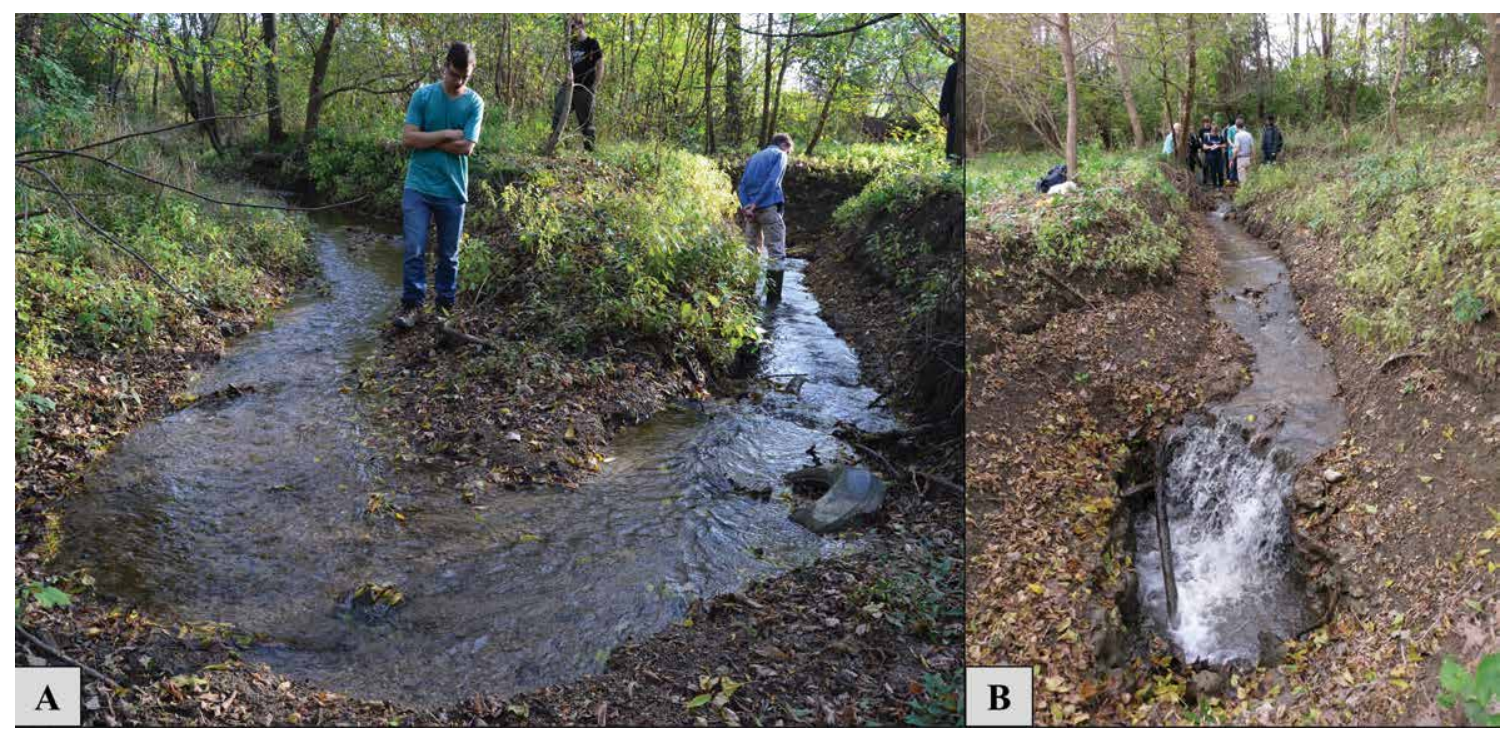

Figure 6. A) Photo showing the channel that was created as the sinking stream formed and diverted all of the stream. The enlargement of the sinkhole and ultimate development of the sinking stream, following the flooding event of 2015, significantly changed the stream gradient and geomorphology of the stream channel. The angle of this capture is much less than $90^{\circ}$; and $\mathrm{B}$ ) photo showing the new channel created by the sinking stream.

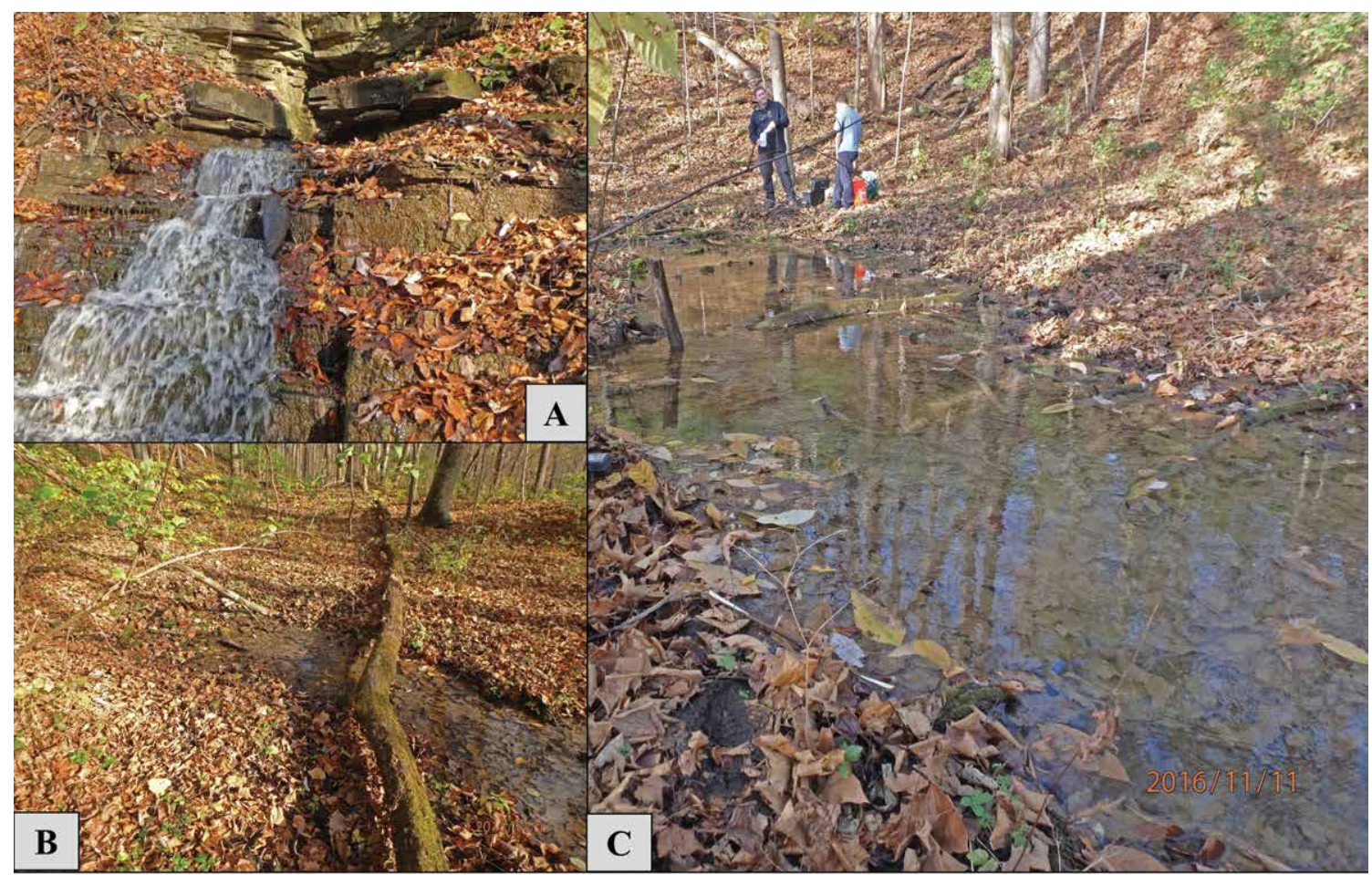

Figure 7. A) Spring 1, the emergence of this spring is approximately $75 \mathrm{~cm}$ wide; B) Spring 2, the spring-run is approximately $61 \mathrm{~cm}$ wide, immediately below the emergence; and C) Spring 3, the author, wearing a black jacket in the background, is $1.85 \mathrm{~m}$ tall for reference. bers were also stationed along the lower reaches of the stream channel to watch for dye breakthrough directly into the streambed. The salt-slug was poured into the sinkhole at 17:05 EST. The leveloggers were set to record $\mathrm{SpC}$ at ten-second intervals and left in the springs overnight. Leveloggers were retrieved on 12 November 2016 at 11:36 EST (Spring 1), $11: 45$ EST (Spring 2), and 11:47 EST (Spring 3). BTCs were created for each of the spring locations.

\section{Stream and Spring Discharge Measurement}

During the third visit on November 11, 2016, a water mass-balance was created for the glen to assess water partitioning in the carbonate aquifer. We were specifically interested in determining how much of the total spring discharge was derived from the allogenic recharge at the sink-

ing stream. In the case where all the spring discharge is derived from the allogenic recharge, the water mass-balance for the glen is given by: $Q_{\mathrm{Str} 1}-Q_{\mathrm{Spr} 1}-Q_{\text {trib }}=0$; where $Q_{\mathrm{Str} 1}$ is the discharge measured at Stream 1 (this is the water entering the sinking stream), $Q_{\mathrm{Spr} 1}$ is the discharge measured at Spring 1 , and $Q_{\text {trib }}$ is the combined discharge measured at Springs 2 and $3\left(Q_{\mathrm{Spr} 2}+Q_{\mathrm{spr} 3}\right)$. Salt-dilution techniques were used to measure the discharge of each individual spring in its spring-run and in the stream uphill of the sinking stream using separate salt-slugs. The discharge of the stream entering the sinking stream $\left(Q_{\mathrm{Str} 1}\right)$ was measured before the stream entered the sinking stream (Stream 1, Fig. 2). A Solinst Model 3001 LTC Junior LTC levelogger was placed downstream at a distance equal to 10× the width of the stream from where the salt-slug was going to be dumped. The salt-slug was then dumped and the SpC was recorded. 
Once the slug breakthrough was complete at each site, the data were downloaded from the sonde and discharge was calculated based on the relationship between salt ( $\left.\mathrm{Cl}^{-}\right)$content and SpC (Moore, 2005; Payn et al., 2009). In our case, $\mathrm{Cl}^{-}{ }_{\text {mass }}=0.0006 \times \mathrm{SpC}$; where $\mathrm{Cl}^{-}{ }_{\text {mass }}$ is the concentration of chloride in $\mathrm{g} \mathrm{L}^{-1}$. A salt-slug was dumped into each individual spring-run, and a Solinst levelogger was placed downstream at a distance approximately equal to $10 \times$ the width of the spring-run where the slug was dumped. The salt-breakthrough was recorded in the same fashion as described above. We quantified the uncertainty in the salt-dilution discharge technique to range from \pm 5 to $\pm 10 \%$ by comparing salt-dilution discharge with independently gauged discharge at stations located outside the catchment. This range is consistent with the uncertainty of $\pm 5 \%$ reported in Day (1976).

\section{Geochemical and Stable Isotope Analyses}

Water samples were collected for geochemical (major element) and stable isotope analyses during the third visit prior to dumping the salt-slug. Two $250 \mathrm{~mL}$ water samples were collected from each of the sites, and were filtered in the field using a peristaltic pump and Geotech $0.45 \mathrm{~mm}$ canister type filters. All water samples were stored in a refrigerator until they were analyzed by the Analytical Chemistry Laboratory of the New Mexico Bureau of Geology and Mineral Resources. Stable isotopes of water $\left({ }^{2} \mathrm{H}\right.$ and $\left.{ }^{18} \mathrm{O}\right)$ were analyzed by the Purdue Stable Isotope Lab using an LGR Triple Isotope Liquid Water Analyzer. The isotopic ratios, $\delta^{2} \mathrm{H}$ and $\delta^{18} \mathrm{O}$, were calculated relative to VSMOW (Vienna Standard Mean Ocean Water). A YSI Professional Plus multiparameter sonde was used to measure field chemistry including $\mathrm{pH}$, temperature $\left({ }^{\circ} \mathrm{C}\right)$, dissolved oxygen (DO; in percent and $\mathrm{mg} \mathrm{L}^{-1}$ ), and oxidation-reduction potential (ORP; $\mathrm{mV}$ ). Total dissolved solids (TDS; $\mathrm{mg} \mathrm{L}^{-1}$ ) was calculated by the sonde using TDS $=0.65 \times \mathrm{SpC}$.

\section{Determination of Karst Hydrogeological Parameters}

QTRACER2 (Florea and Wicks, 2001; Field, 2002), an Environmental Protection Agency (EPA) software, was used to estimate the hydrogeological parameters of the karst network by entering the data from the salt-breakthrough curves. The following parameters were calculated for each spring using QTRACER2 and the measured BTC data: time to leading edge $\left(t_{\mathrm{le}}\right)$, time to peak $\left(t_{\mathrm{pk}}\right)$, peak concentration $\left(C_{p k}\right)$, percent salt-mass recovery, mean transit time $(M T T)$, Peclet number $(P e)$, and cross-sectional area of flow $(A)$. Please refer to Field (2002) for detailed explanations on how these parameters are calculated in QTRACER2. We created BTCs and calculated percent salt-mass recovery for each spring using Excel. The percent salt-mass recovery can be calculated from

$$
M=Q \int_{0}^{\infty} C(t) d t
$$

where: $M=$ mass of chloride recovered $(\mathrm{g}), Q$ is spring discharge $\left(\mathrm{L} \mathrm{s}^{-1}\right.$ and assumed to be constant through the duration of the salt-tracer test), and $C(t)$ is the chloride concentration as a function of time (Jones, 2012). The integral was evaluated over the time when the slug was dumped $(t=0)$ to the time the levelogger was retrieved $\left(t=t_{\text {final }}\right)$. We compared the QTRACER2 calculations for $t_{\mathrm{le}}$ and $t_{\mathrm{pk}}$ to field observations and hand calculations, respectively.

\section{Results}

\section{Salt- and Dye-Tracing Tests}

BTCs were successfully captured at each spring site (Fig. 8). The timing of the initial breakthrough was approximately the same for all three springs despite significantly different radial distances between the sinking stream and the outflow at the springs (Table 1). The salt-slug emerged after 2.4 hours at both Spring 2 and Spring 3, and after 2.7 hours at Spring 1. There are subtle differences in the BTCs for each spring. Spring 1 has a single-peaked BTC with a fast rise and fast recession on the salt-pulse and relatively short tail (Figure 8A, B). Springs 2 and 3 both have double-peaked (bi-modal) recovery curves, with the first peak occurring after 2.4 hours and the second peak occurring after 3.1 hours. The BTC of Spring 2 has a substantially longer tail than Spring 1 or Spring 3 (Fig. 8A). Total chloride recovery was 51.2 $\%$, calculated using QTRACER2, and the majority of the chloride mass was recovered at Spring 1 and Spring 3 (Table 1). Our hand calculations show that $49.9 \%$ of the chloride mass was recovered at the three springs; a difference of 1.3 $\%$.

\section{Discharge and Water Mass-Balance}

Since the main channel of the stream was dry between the sinking stream and Spring 1, surface flow in the channel in the lower reaches of the catchment is due almost exclusively to water discharged from Spring 1 . The only other source of water to the stream is the small, western tributary, which is sourced from Springs 2 and 3 (Fig. 2). The measured discharge at Stream $1, Q_{\mathrm{Str} 1}$, is $10.9 \mathrm{~L} \mathrm{~s}^{-1}$, the measured discharge at Spring $1, Q_{\mathrm{Spr} 1}$, is $4.3 \mathrm{Ls}^{-1}$, and the combined discharge at Springs 2 and $3, Q_{\text {trib }}$, is $7.0 \mathrm{~L} \mathrm{~s}^{-1}$. Thus, the combined discharge of the springs is $0.4 \mathrm{~L} \mathrm{~s}^{-1}$ greater than the discharge of the stream entering the sinking stream, possibly indicating that the sinking stream is not the only source of water emerging from the springs. This is consistent with the landowners' observations that the springs were flowing before the sinking stream formed. However, given the uncertainty in our discharge measurements, it is difficult to determine how much 

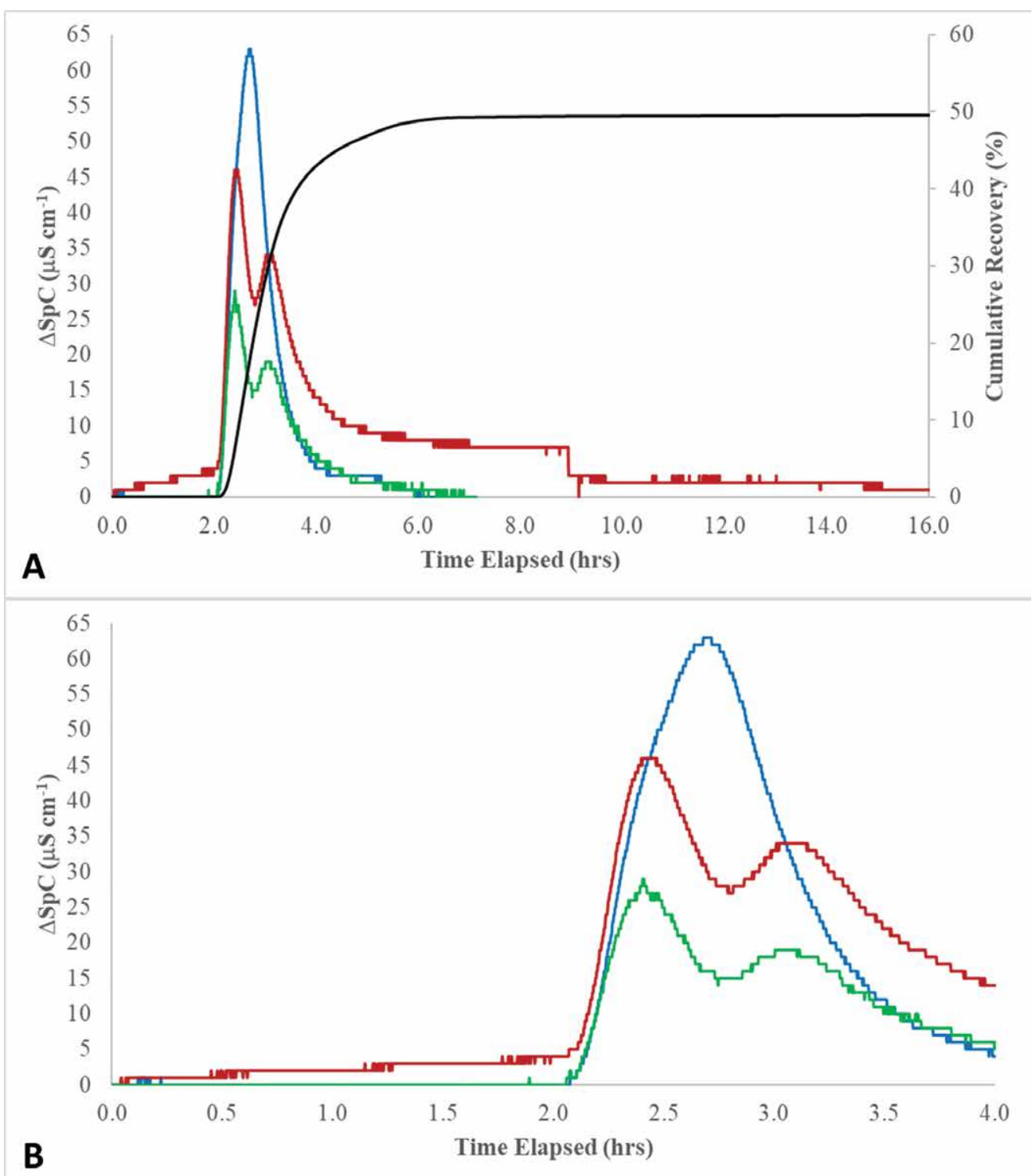

Figure 8. A) Breakthrough curve for Spring 1 (blue line), Spring 2 (red line), Spring 3 (green line), and cumulative recovery (black line); and B) close-up of breakthrough showing early breakthrough at Spring 2. actual groundwater emerged from the springs before the sinking stream developed.

\section{Geochemical and Stable Isotopic Results}

The field chemistry (Table 2) and the geochemistry (Table 3 ) of the water entering the sinking stream is similar to the water discharging from the springs. The DO content of Stream 1 and Spring 1 are similar (Table 2) and consistent with surface water, not groundwater. Thus, Spring 1 discharges a large proportion of water that is either in equilibrium with the atmosphere or the oxygen has not been thoroughly used in geochemical reactions (namely redox reactions) or in the decomposition of organic matter in the aquifer. However, the lower DO content of Springs 2 and 3 (Table 2) indicates that these springs discharge a larger proportion of groundwater not sourced from allogenic recharge. The stable isotopic compositions of Stream 1 and all springs are relatively similar (Table 3), plot on the local meteoric water line (LMWL) given by $\delta^{2} \mathrm{H}=7.8\left(\delta^{18} \mathrm{O}\right)+$ 9.3 (Bowen et al., 2007), and do not show evidence of evaporation.

\section{QTRACER2 Results}

The data for the second salt-slug test conducted during the third site visit was analyzed using QTRACER2 (Table 1). The time to leading edge $\left(t_{\mathrm{le}}\right)$ was shorter for Spring 3 than for Spring 1 . This is consistent with the observed dye breakthrough on the first salt-slug test. The mean transit time was shorter for Spring 1 (3.0 hours) than Spring 3 (3.2

Table 1. Summary of the salt-slug test and QTRACER2 analyses.

\begin{tabular}{|c|c|c|c|c|c|c|c|c|c|}
\hline Site & Distance $^{\mathrm{a}}, \mathrm{m}$ & $t_{\mathrm{le}}^{\mathrm{b}}, \mathbf{h}$ & $t_{\mathrm{pk}}^{\mathrm{c}}, \mathbf{h}$ & $C_{\mathrm{pk}}^{\mathrm{d}}, \boldsymbol{\mu} \mathrm{S} \mathrm{cm}^{-1}$ & $M T T^{\mathrm{e}}, \mathbf{h}$ & $A^{\mathrm{f}}, \mathrm{m}^{2}$ & $P e^{g}$ & $M^{\mathrm{h}}, \mathbf{g}$ & Recoveri, \% \\
\hline Spring 1 & 150 & 2.1 & 2.7 & 586 & 3.0 & 0.30 & 319 & 542 & 24.6 \\
\hline Spring 2 & 315 & 2.1 & 2.4 & 580 & 3.6 & 0.21 & 293 & 81 & 3.7 \\
\hline Spring 3 & 318 & 1.9 & 2.4 & 526 & 3.2 & 0.26 & 366 & 504 & 22.9 \\
\hline
\end{tabular}

a Straight-line distance measured from the swallow hole to the spring.

${ }^{\mathrm{b}} t_{\mathrm{le}}$ is the time to the leading edge of the salt-slug pulse equivalent to the arrival time.

${ }^{\mathrm{c}} t_{\mathrm{pk}}$ is the time to the peak of the salt-slug peak.

${ }^{d} C_{p k}$ is the peak conductivity of the salt-slug pulse.

e $M T T$ is the mean transit time for the salt-slug.

${ }^{f} A$ is the cross-sectional area for flow.

${ }_{9} \mathrm{Pe}$ is the Peclet number.

${ }^{\mathrm{n}} \mathrm{M}$ is the amount of chloride recovered.

' Recover is the percent of total chloride recovered 
Table 2. Field chemistry data.

\begin{tabular}{|c|c|c|c|c|c|c|}
\hline Site & $\mathrm{pH}$ & $\mathrm{T},{ }^{\circ} \mathrm{C}$ & $\mathrm{SpC}, \mu \mathrm{s} \mathrm{cm}^{-1}$ & TDS, mg L-1 & DO, \% & DO, $\mathrm{mg} \mathrm{L}^{-1}$ \\
\hline Stream 1 & 8.2 & 11.3 & 746 & 481 & 100 & 11.1 \\
\hline Spring 1 & 8.0 & 11.1 & 731 & 475 & 90 & 9.9 \\
\hline Spring 2 & 7.8 & 11.4 & 732 & 474 & 63 & 6.9 \\
\hline Spring 3 & 7.7 & 11.4 & 701 & 465 & 47 & 5.0 \\
\hline
\end{tabular}

Note: $\mathrm{T}=$ temperature, $\mathrm{SpC}=$ specific conductivity at $25^{\circ} \mathrm{C}, \mathrm{TDS}=$ total dissolved solids, and $\mathrm{DO}=$ dissolved oxygen.

Table 3. Geochemical and stable isotopic data.

\begin{tabular}{|c|c|c|c|c|c|c|c|c|c|}
\hline Site & $\mathrm{Ca}^{2+}, \mathrm{mg} \mathrm{L}^{-1}$ & $\mathrm{Na}^{+}, \mathrm{mg} \mathrm{L}^{-1}$ & $\mathrm{~K}^{+}, \mathrm{mg} \mathrm{L}^{-1}$ & $\mathrm{Sr}^{2+}, \mathrm{mg} \mathrm{L}^{-1}$ & $\mathrm{Cl}^{-}, \mathrm{mg} \mathrm{L}^{-1}$ & $\mathrm{NO}_{3}^{-}, \mathrm{mg} \mathrm{L}^{-1}$ & $\mathrm{HCO}_{3}^{-}, \mathrm{mg} \mathrm{L}^{-1}$ & $\delta^{2} \mathrm{H}, \%$ & $\delta^{18} \mathrm{O}, \%$ \\
\hline Stream 1 & 96 & 14 & 2.3 & 0.21 & 27 & 11.0 & 377 & -49.1 & -7.29 \\
\hline Spring 1 & 100 & 13 & 2.1 & 0.22 & 26 & 11.0 & 389 & -49.0 & -7.34 \\
\hline Spring 2 & 101 & 13 & 2.1 & 0.22 & 23 & 11.0 & 389 & -49.2 & -7.18 \\
\hline Spring 3 & 97 & 11 & 1.9 & 0.24 & 18 & 9.3 & 389 & -48.5 & -7.35 \\
\hline
\end{tabular}

hours) and Spring 2 (3.6 hours) suggesting that Spring 1 is controlled by purely advective flow along highly-connected flowpaths or perhaps one large conduit to the spring. The double-peaked (bi-modal) BTC and longer tail in the BTCs for Spring 2 and Spring 3 suggest that bifurcation of flowpaths or anastomosing flowpaths occur to these springs (Smart and Ford, 1982; Goldscheider et al., 2008; Field and Leij, 2012). The longer tail of the Spring 2 BTC may also be explained by the presence of pooling along the flowpaths, which has been shown to retard flow (Hauns et al., 2001).

Peclet numbers are dimensionless numbers representing the ratio of the advective transport rate to the diffusive transport rate. A Pe less than 1 indicates a diffusion-dominated flow system while, in comparison, a $P e$ greater than 1 indicates an advection-dominated flow system. All three springs had Pe greater than 290 indicating the karst aquifer is strongly advection dominated. This is relatively common in karst aquifers (Field and Nash, 1997; Covington and Perne, 2015; Luhmann et al., 2015). Based on these data, the calculated cross-sectional area for flow of Spring $1\left(0.30 \mathrm{~m}^{2}\right)$ was larger than the cross-sectional area for Spring 2 and Spring 3, $0.21 \mathrm{~m}^{2}$ and $0.26 \mathrm{~m}^{2}$, respectively (Table 1). Total chloride-mass recovery was $51.2 \%$. Springs 1 and 3 accounted for the majority of chloride-mass recovery (24.6 and $22.9 \%$, respectively). Only $3.7 \%$ of the chloride mass was recovered at Spring 2.

\section{Discussion}

The shape of the BTC for Spring 1 (single peak with rapid rise and rapid recession in chloride breakthrough) is indicative of advective flow with little bifurcation and/or flow through the trunk conduit of a conduit-dominated system. The high DO content (90\%), and high $P e(319)$ for Spring 1 indicate that this spring is well-connected to the sinking stream. However, since this spring was active before the sinking stream formed, the high DO suggests that the spring must discharge a large proportion of water that is either flowing quickly through the karst network, or, is in equilibrium with the atmosphere. One possibility is that the spring is hydraulically connected to a lake in a limestone quarry located east of the property (see Fig. 2B). Field observations and regional geologic maps (Wayne et al., 1966) indicate that there is a slight westerly dip to the rocks. The surface-elevation of the emergence for Spring 1 (182 m.a.s.I.) is approximately equal to the surface-elevation of the lake in the quarry (178 to 183 m.a.s.l.), thus we cannot rule out the possibility that Spring 1 is also connected to the lake. We could not sample the lake for stable isotopic analyses since it is located on private property; however, we expect the stable isotopic ratios of the lake water to show some evaporation effects, and that this evaporated signal would be present in Spring 1. Published evaporation rates for lakes in northern Indiana indicate that the evaporation rate can reach $78.7 \mathrm{~cm} \mathrm{y}^{-1}$ (Perrey and Corbett, 1956) and the surface area of the quarry lake is large $\left(\sim 77,500 \mathrm{~m}^{2}\right)$. Combined with the published evaporation rates, we would expect to see a mixture of allogenic recharge and evaporated lake water discharging at Spring 1. We do not see evidence for evaporation in the water samples collected at Spring 1, although, we cannot rule out this possibility until we have samples from the lake. A second possibility is that Spring 1 is connected to another sinking stream in the area. Because there are no streams in the immediate vicinity of the spring (or in closer proximity than the lake), this explanation seems less likely than the hydraulic connection to the lake. A third possibility is that streamflow is lost to the bed upstream of the sinking stream. This could explain the presence of Spring 1 before the stream piracy event. In any case, it appears that at least $24 \%$ to $25 \%$ of the recharge from the sinking stream must discharge at Spring 1, based on chloride-mass recovery. These data suggest a short, direct connection between the sinking stream and Spring 1, as indicated by the greater calculated cross-sectional area for Spring 1.

The shape of the BTC for Springs 2 and 3 are both double-peaked (bi-modal; Fig. 8B) indicating bifurcation in the flowpaths or anastomosing flowpaths to the springs (Smart, 1988; Goldscheider et al., 2008). The BTC of Spring 2 
showed a much longer tail than either of the other springs (Fig. 8). Long tails in flowpath distributions are common indicators of greater storage and/or slower flowpaths (Frisbee et al., 2013), retention of chloride mass along conduits or sediment in conduits of the aquifer (Drummond et al., 2012), and/or retardation of flow due to the presence of pooling (Hauns et al., 2001). We infer that the long tail in the BTC of Spring 2 indicates that some of the chloride mass was dispersed along slower flowpaths, located deeper in the karst aquifer. Recall that the emergence for Spring 1 is located approximately four meters above the modern stream elevation, whereas the emergences for Springs 2 and 3 are located nearer to the outlet and at an elevation that is only slightly higher than the stream elevation. The flowpaths must travel beneath the streambed or else the streambed springs would discharge water to the stream. Instead, since Springs 4 and 5 are now dry, this seems to indicate that the flowpaths connecting the sinking stream to Springs 2 and 3 must flow deep within the planar-bedded, fine-grained limestone. The flow then bifurcates vertically and laterally along the fractured planar beds. The streambed springs (Springs 4 and 5), in comparison, must be driven by short exchanges of water along interconnected, karst conduits, localized to the streambed, reminiscent of hyporheic zone flow in perennial sediment-bedded streams (Boulton et al., 1998; Wilson and Henry, 2013).

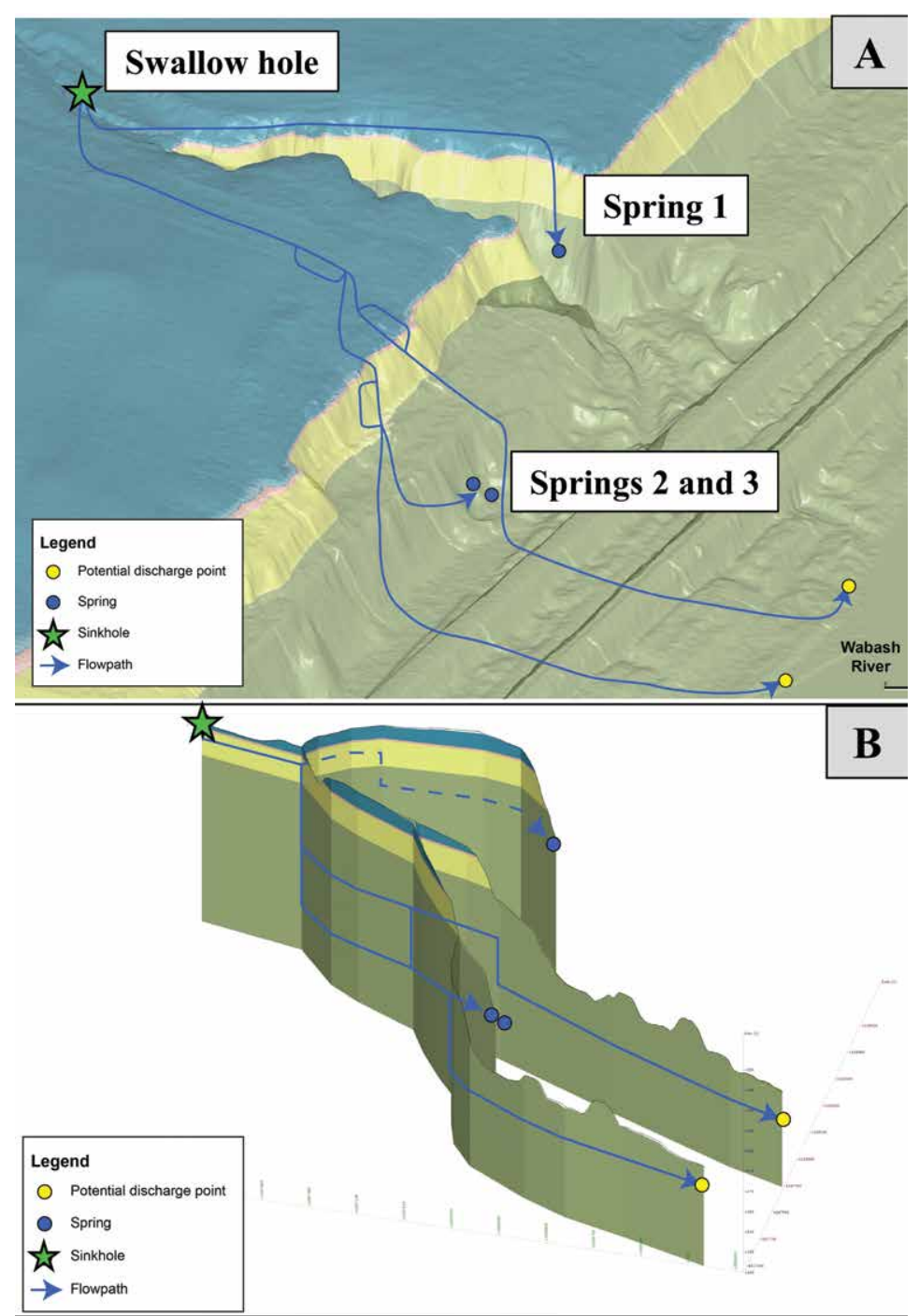

Figure 9. Conceptual flow model built using Leapfrog Hydro. A) Mapview illustrating possible lateral changes in flowpath lengths and tortuosities. Please note that the blue flowpaths do not follow or flow along the land-surface; they are shown relative to the land-surface. The loops in the flowpaths represent the lateral bifurcation of subsurface flowpaths. B) Cross-section view showing vertical changes in flowpath lengths and tortuosities. The upper teal-colored unit is the massive, fine-grained, fractured to nodular limestone layer shown in Figure 4B, the thin, pink layer is the silty facies of the limestone, also shown in Figure 4B. The yellow layer is the massive, nodular limestone, and the olive drab layer is the planar-bedded limestone layer shown in Figure 4C.
The conceptual flow model (Fig. 9) was developed based on the field observation, BTCs, and QTRACER2 results. The arrival times are a little faster at Springs 2 and 3 despite much longer lateral distances from the sinking stream to these springs $(315 \mathrm{~m}$ and $317 \mathrm{~m}$, respectively) as compared to the distance to Spring $1(150 \mathrm{~m})$. We infer that once the water enters the sinking stream, it flows along one conduit down to the top of a planar-bedded rock layer. At this point, the flowpaths must diverge, some of the water ( $25 \%$, based on chloride-mass recovery) flows toward Spring 1 along either one, large conduit or a group of highly-interconnected conduits, creating the single-peaked BTC (Fig. 8). The remainder ( $75 \%$, based on chloride-mass recovery) of the water must flow toward Springs 2 and 3 . However, Springs 2 and 3 accounted for $3.7 \%$ and $22.9 \%$, respectively, of the chloride-mass recovery, indicating that $48.8 \%$ of the chloride mass did not discharge through the three monitored springs. We infer that the double-peaked BTC is created by bifurcation of flowpaths and/ or anastomosing flowpaths in the planar-bedded facies, and these flowpaths converge prior to reaching Springs 2 and 3 (Fig. 9).

Approximately $51.2 \%$ of the chloride mass was recovered $\left[\mathrm{Cl}^{-}\right.$mass recovered $=\mathrm{Cl}^{-}$(Spring 1) + $\mathrm{Cl}^{-}$(Spring 2) $+\mathrm{Cl}^{-}$(Spring 3)]. It is rare to recover $100 \%$ of a tracer since tracer mass may be retained or sorbed onto sediments in the aquifer or in longer flowpaths, or it may discharge at unmonitored discharge sites (Benischke et al., 2007). In Fitch's Glen, we propose three likely possibilities for the remaining chloride mass: 1) chloride mass was retained along deeper karst flowpaths; 2) chloride mass was discharged to other springs that were not found in the field; or 3) chloride mass was discharged directly to the Wabash River. The first explanation is supported by the very long tail observed in the BTC of Spring 2 (Fig. 8) and the third explanation is plausible given the relatively fast arrival times at Springs 2 and 3, and their close proximity to the Wabash River $(\sim 175 \mathrm{~m}$ from Springs 2 and 3 to the Wabash River; Fig. 2). We searched for other springs near Springs 2 and 3, but 


\section{Pre-Glacial Time}
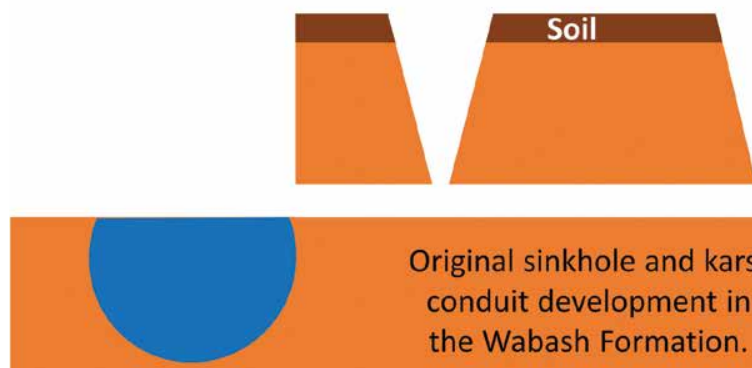

Original sinkhole and karst conduit development in the Wabash Formation.

\section{Post Glacial Time}

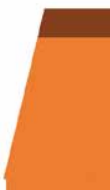

A

\section{Last Glacial Maximum}
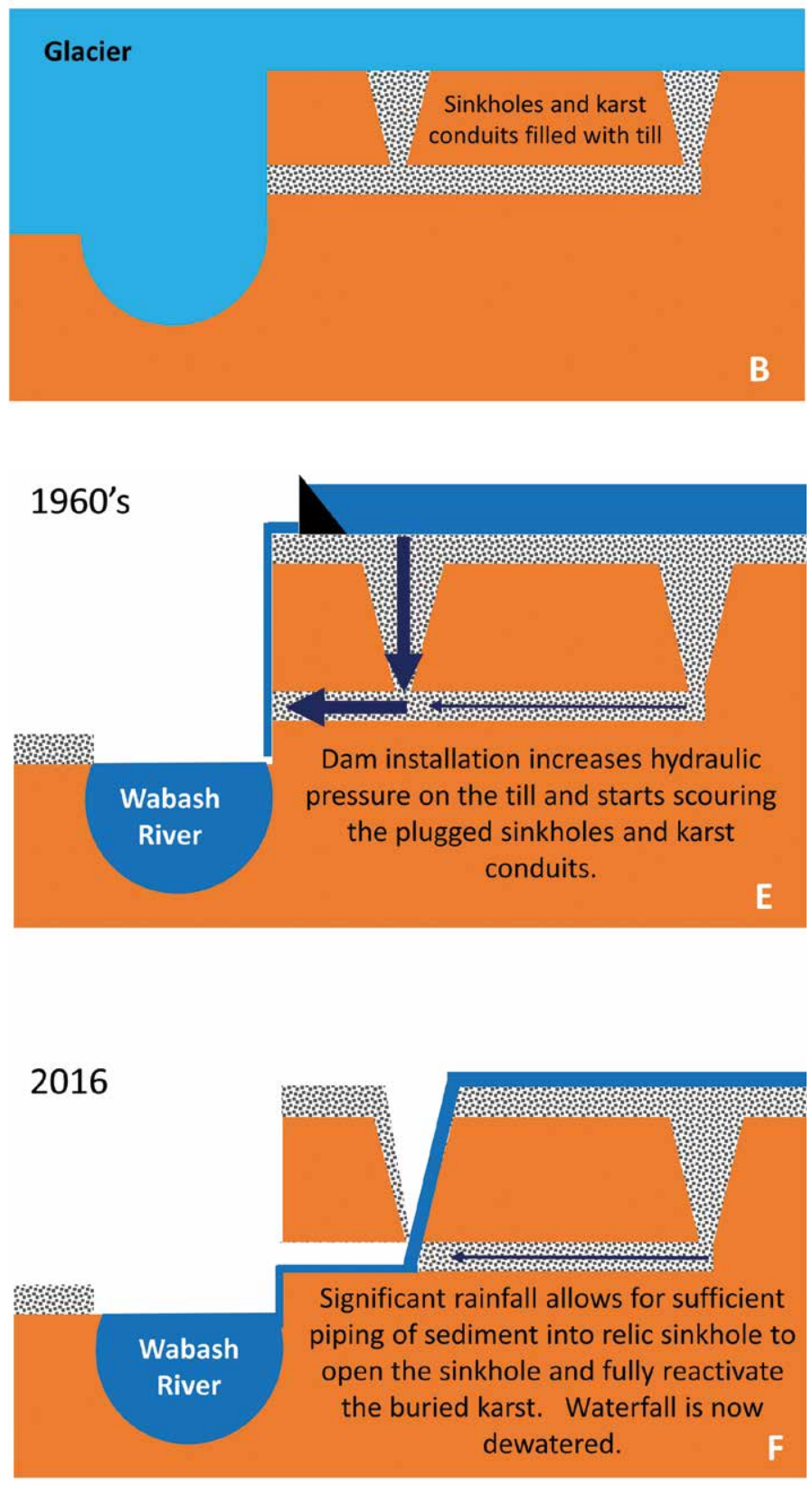
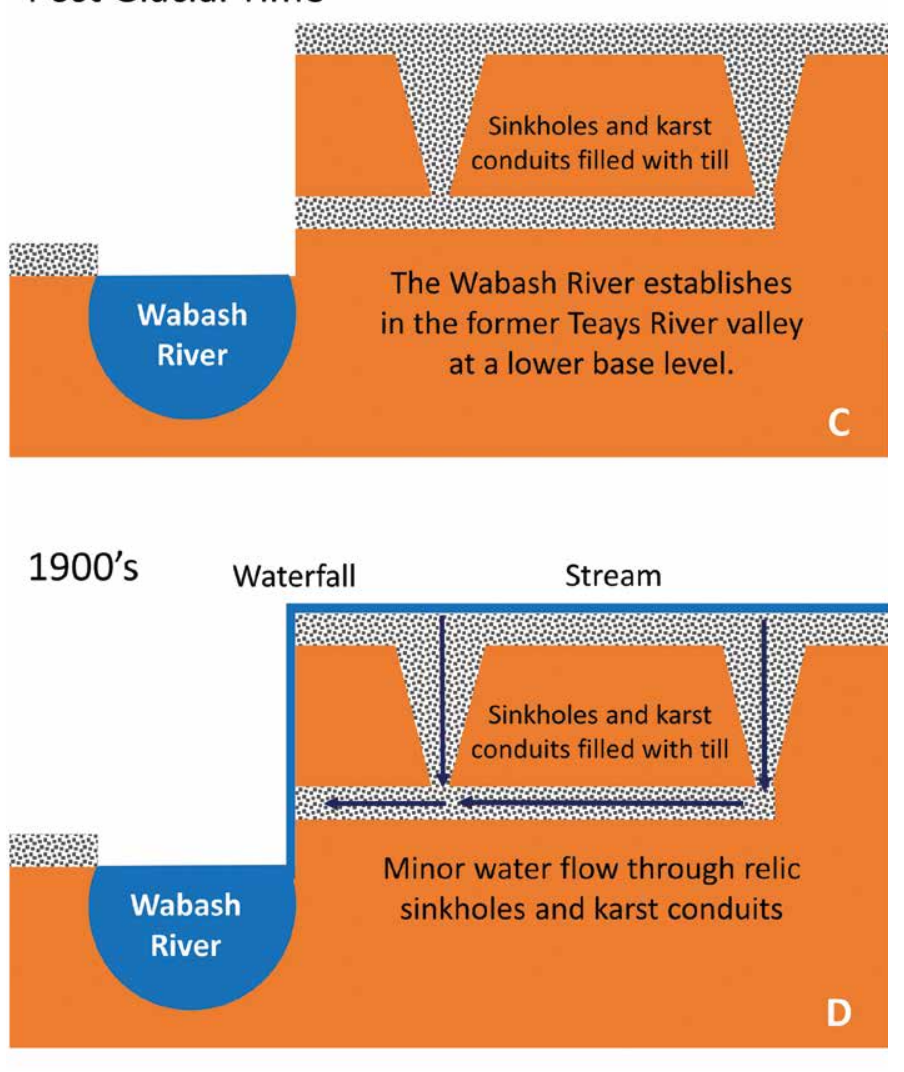

Figure 10: Simplified conceptual model for the re-activation of the sinkhole. A) Cross-section showing karst features prior to glaciation, B) Advance of glacier over the landscape, C) Burial of karst with glacial sediment, D) Thin arrows represent minimal flow of water through buried karst, E) Ponding after dam construction, where thick arrows represent increased hydraulic head, which dislodges sediment in buried karst openings, and F) Re-activation of sinking stream following widespread flooding in 2015.

were unable to locate any on the property. This does not rule out the possibility that chloride mass discharged via regional-scale flowpaths to springs on adjacent property, outside the surface-water divide of the catchment. This is especially true, where the stratigraphy of a catchment conforms largely to a layer-cake model (horizontal bedding with little-to-no dip), and delineation of well-defined topographic watershed divides is difficult. These characteristics are also common in karst settings (Runkel et al., 2013).

We developed a conceptual model explaining the activation (re-activation) of the buried karst sinkhole, based on field observations (especially buried karst features such as the presence of shafts and large conduits), historical hydrological modifications, and tracer test data (Fig. 10). Preexisting karst was buried when glacial activity deposited till on top of the carbonate rock and open conduits and/ or sinkholes (Fig. 10A). Surface erosion removed some of the sediment from the top of the buried karst and activated the paleosinkholes. The presence of abandoned shafts supports the inference that these paleosinkholes have 
been activated sporadically in the past. The dam was built in the 1960s, and ponding upstream of the dam increased the hydraulic head on the buried karst, which likely provided sufficient stress to begin washing some of the sediment out of the till-filled karst conduits in the carbonate rock (Fig. 10E), which has been documented elsewhere (e.g., Milanović, 2005; Upchurch et al., 2013; Veress, 2016). The extremely rainy summer of 2015 caused persistent flooding that flushed sediment from the buried karst conduit and formed the sinking stream, which eventually swallowed the stream. (Fig. 10F).

\section{Conclusion}

We addressed three primary questions in this study: 1) how did the sinkhole/sinking stream become re-activated in the buried karst, 2) where did the streamflow (allogenic recharge) go once it entered the sinking stream, and 3) what transport processes are active in the carbonate rocks at Fitch's Glen? The second and third questions are easier to answer because the data clearly show a hydrological connection between the sinking stream and three springs, while breakthrough curves and QTRACER2 results show strong evidence for advection-dominated flow in the karst with bifurcation occurring along deep flowpaths. Approximately $51 \%$ of the chloride mass was recovered during the second salt-slug test leaving $49 \%$ unaccounted for in the test. Based on the shapes of the BTC, average flow velocities, and close proximity to the Wabash River, we infer that some of the chloride mass and water from the sinking stream must discharge directly to the Wabash River, other springs, and/or some may be retained along slow and/or deep flowpaths in the carbonate aquifer. Regarding the first question, it is clear that land-use changes have played a role in the current hydrogeological behavior of this system. The area upstream of the old dam has numerous buried sinkholes, which may one day become reactivated and form sinking streams. We infer that the combination of land-use change (ponding following the installation of the dam), presence of buried karst, and an extremely rainy year with widespread flooding worked together to re-activate the karst sinking stream present today.

Google Earth imagery (Fig. 5) shows that sinkholes have been present in the landscape since at least 1998, and field reconnaissance indicates that there are numerous inactive sinkholes (i.e., plugged conduits) near the existing active sinkhole today. In addition, the presence of the vertical shafts and large conduits further down the valley indicate that there have been active sinking streams with connectivity to large springs in the past. In fact, the location of these suggests that these sinkholes and their associated springs may have contributed to the development of this small, limestone canyon in a landscape that is otherwise extremely flat. It is beyond the scope of this article to describe potential remediation techniques in great detail (examples can be found in Zhou and Beck, 2008); however the presence of the numerous inactive sinkholes near the modern sinking stream suggests that remediation techniques may only provide a temporary fix to the problem.

\section{Acknowledgements}

We would like to thank the landowners, Kevin Coryea and Dee Dee Neumeyer, for their help and generosity. Also, we thank Laura Alejandra Beltrán Daza, Benjamin Sadler, and Catherine Wilsbacher for field assistance. Research expenses were covered by start-up funding from Purdue University. We thank Benjamin Schwartz (Associate Editor), Malcolm Field (Editor-in-Chief), and three anonymous reviewers for their constructive feedback on this article. We thank Lee J. Florea for providing a review and helpful discussions on the article.

\section{References}

Armstrong, R., and Osborne, L., 2003, Paleokarst: Cessation and rebirth?, Speleogenesis and Evolution of Karst Aquifers: The Virtual Scientific Journal, v. 1, no. 2, p. 1-10.

Bassett, J.L., 1974, Hydrology and geochemistry of karst terrain, Upper Lost River Drainage Basin, Indiana, [M.A. Thesis]: Bloomington, Ind., Indiana Univeristy, $102 \mathrm{p}$.

Bassett, J.L. and Ruhe, R.V., 1974, Geomorphology, hydrology, and soils in karst, southern Indiana, Field Conference, April 24-25: Bloomington, Indiana, Indiana Water Resources Research Center, Indiana University, 54 p.

Bayless, E.R., Taylor, C.J., and Hopkins, M.S., 1994, Directions of ground-awter flow and locations of ground-water divides in the Lost River Watershed near Orleans, Indiana: U.S. Geological Survey, Water-Resources Investigations Report 94-4195, 25 p.

Bedrock Geology of Indiana, Indiana Geological and Water Survey, Indiana University, https://igs.indiana.edu/Bedrock/, [last accessed on June 28, 2018].

Benischke, R., Goldscheider, N., and Smart, C., 2007, Tracer techniques, in Goldscheider, N. and Drew, D., Methods in Karst Hydrogeology, p. 147-170.

Bosák, P., Ford, D.C., and Glazek, J., 1989, Terminology, in Bosák, P., Ford, D.C., Glazek, J., and Horáček, eds., Paleokarst: A Systematic and Regional Review, Elsevier and Academia, Amsterdam and Praha, $726 \mathrm{p}$.

Boulton, A.J., Findlay, S., Marmonier, P., Stanley, E.H., and Vallett, H.M., 1998, The functional significance of the hyporheic zone in streams and rivers: Annu. Rev. Ecol. Syst., v. 29, p. 59-81. https://doi.org/10.1146/annurev.ecolsys.29.1.59.

Bowen, G. J., Ehleringer, J.R., Chesson, L.A., Stange, E., and Cerling, T.E., 2007, Stable isotope ratios of tap water in the contiguous United States: Water Resources Research, v. 43, p. W03419. https://doi.org/10.1029/2006WR005186.

Bright Dyes Technical Data Bulletin, https://brightdyes.com/wp-content/uploads/2018/02/TDS-106000.pdf; [last accessed on June 28, 2018].

Buglosi, E.F., 1997, The Midwestern Basins and Arches Regional Aquifer System in parts of Indiana, Ohio, Michigan, and Illinois - Summary,

U.S. Geological Survey, Professional Paper 1423-A, 60 p. 
Frisbee, Meyers, Miller, Gleason, Stewart-Maddox, Larson, Granger, Saksena, Dey, and Frisbee

Casey. G.D., 1997, Hydrogeologic framework of the Midwestern Basins and Arches Region in parts of Indiana, Ohio, Michigan, and Illinois, U.S. Geological Survey, Professional Paper 1423-B, 54 p.

Covington, M.D. and Perne, M., 2015, Consider a cylindrical cave: A physicist's view of cave and karst science: Acta Carsologica, v. 44, no. 3, p. 363-380.

David Dian Zhang, Yingjun Zhang, An Zhu, and Xing Cheng, 2001, Physical mechanisms of River Waterfall Tufa ( Travertine ) Formation: Journal of Sedimentary Research, v. 71, p. 205-216. https://doi.org/10.1306/061600710205.

Day, T.J., 1976, On the precision of salt dilution gauging: Journal of Hydrology, v. 31, 293-306. https://doi.org/10.1016/0022-1694(76)90130-X.

Drummond, J.D., Covino, T.P., Aubeneau, A.F., D. Leong, Patil, S., Schumer, R., and Packman, A.I., 2012, Effects of solute breakthrough curve tail truncation on residence time estimates: A synthesis of solute tracer injection studies: Journal of Geophysical Research, v. 117, p. G00N08, https://doi/org/10.1029/2012JG002019.

Dussart-Baptista, L., Massei, N., Dupont, J.P., and Jouenne, T., 2003, Transfer of bacteria-contaminated particles in a karst aquifer: Evolution of contaminated materials from a sinkhole to a spring: Journal of Hydrology, v. 284, p. 285-295, https://doi.org/10.1016/j.jhydrol.2003.08.007.

Duwelius, J.A., Bassett, J.L., and Keith, J.H., 1996, Application of fluorescent dye tracing techniques for delineating sinkhole drainage routes, Highway 37 improvement project, Lawrence County, Indiana: International Journal of Rock Mechanics and Mining Sciences and Geomechanics Abstracts, v. 2.

Eberts, S.M. and George, L.L., 1997, Regional ground-water flow and geochemistry in the Midwestern Basins and Arches Aquifer System in parts of Indiana, Ohio, Michigan, and Illinois, U.S. Geological Survey, Professional Paper 1423-C, 116 p.

Field, M.S., 1992, Karst hydrology and chemical contamination: Journal of Environmental Systems, v. 22, p. 26. https://doi.org/10.2190/X7MVC93E-66GK-BFH7.

Field, M.S., and Nash, S.G., 1997, Risk assessment methodology for karst aquifers: (1) estimating karst conduit-flow parameters: Environmental Monitoring and Assessment, v. 47, p. 1-21. https://doi.org/10.1023/A:1005753919403.

Field, M.S., 2002, The QTRACER2 program for Tracer-Breakthrough Curve Analysis for tracer tests in karstic aquifers and other hydrologic systems, U.S. EPA, EPA/600/R-02/001, $194 \mathrm{p}$.

Field, M.S. and Leij, F.J., 2012, Solute transport in solution conduits exhibiting multi-peaked breakthrough curves: Journal of Hydrology, v. 440-441, p. 26-35. https://doi.org/10.1016/j.jhydrol.2012.03.018.

Florea, L.J. and Wicks, C.M., 2001, Solute transport through laboratory-scale karstic aquifers: Journal of Cave and Karst Studies, v. 63, no. 2, p. 59-66.

Florea, L.J., Hasenmueller, N.R., Branam, T.D., Frushour, S.S., and Powell, R.L., 2018, Karst geology and hydrogeology of the Mitchell Plateau of south-central Indiana, in Florea, L.J., ed., Indianapolis Field Guide, Geological Society of America Field Guide 51, p. 1-18. https://doi. org/10.1130/2018.0051(XX).

Florea, L.J., 2019, Evaluation of karst aquifer water quality associated with agricultural land use in Younos, T., Schreiber, M., and Ficco, K.K., eds., Kasrt Water Environment: Advances in Research, Management and Polcy, p. 157-190. https://doi.org/10.1007/978-3-319-77368-1.

Ford, D.C., 1995, Paleokarst as a target for modern karstification: Carbonates and Evaporites, v. 10, n. 2, p. 138-147. https://doi.org/10.1007/ BF03175399.

Frisbee, M.D., Wilson, J.L., Gomez-Velez, J.D., Phillips, F.M., and Campbell, A.R., 2013, Are we missing the tail (and the tale) of residence time distributions in watersheds?, Geophysical Research Letters, v. 40, p. 4633-4637. https://doi.org/10.1002/grl.50895.

Goldscheider, N., Meiman, J., Pronk, M., and Smart, C., 2008, Tracer tests in karst hydrogeology and speleology: International Journal of Speleology, v. 37, p. 27-40. https://doi.org/10.5038/1827-806X.37.1.3.

Gray, H. H., 2000, Physiographic divisions of Indiana, Indiana Geological Survey Special Report 61, 15 p.

Greene, E.A., 1997, Tracing recharge from sinking streams over spatial dimensions of kilometers in a karst aquifer: Ground Water, v. 35, p. 898-904. https://doi.org/10.1111/j.1745-6584.1997.tb00159.x.

Hallberg, G.R., and Hoyer, B.E., 1982, Sinkholes, hydrogeology, and groundwater quality in northeast lowa: lowa Department of Natural Resources, Geological Survey Bureau, Open File Report 82-83, 120 p.

Hasenmueller, N.R., and Packman, D.M., Karst Features in Indiana, Indiana Geological and Water Survey, https://igs.indiana.edu/bedrock/karst. $\mathrm{cfm}$, [last accessed on June 28, 2018].

Hauns, M., Jeannin, P.-Y., and Atteia, O., 2001, Dispersion, retardation and scale effect in tracer breakthrough curves in karst conduits: Journal of Hydrology, v. 241, p. 177-193. https://doi.org/10.1016/S0022-1694(00)00366-8.

Herczeg, A.L., Leaney, F.W.J., Stadter, M.F., Allan, G.L., and Fifield, L.K., 1997, Chemical and isotopic indicators of point-source recharge to a karst aquifer, South-Australia: Journal of Hydrology, v. 192, p. 271-299. https://doi.org/ 10.1016/S0022-1694(96)03100-9.

Jones, W.K., 2012, Water tracing in karst aquifers, in White, W.B. and Culver, D.C., eds., Encyclopedia of Caves, $2^{\text {nd }}$ Edition, Academic Press, 966 p. https://doi.org/10.1016/B978-0-12-383832-2.00128-6.

Karr, J.R., Toth, L.A., and Dudley, D.R., 1985, Fish communities of midwestern rivers: A history of degradation: BioScience, v. 35, p. 90-95. https://doi.org/10.2307/1309845.

Lee, E.S., and Krothe, N.C., 2001, A four-component mixing model for water in a karst terrain in south-central Indiana, USA. Using solute concentration and stable isotopes as tracers: Chemical Geology, v. 179, p. 129-143. https://doi.org/ 10.1016/S0009-2541(01)00319-9.

Lindsey, B.D., Katz, B.G., Berndt, M.P., Ardis, A.F., and Skach, K.A., 2010, Relations between sinkhole density and anthropogenic contaminants in selected carbonate aquifers in the eastern United States: Environ. Earth Sci., v. 60, p. 1073-1090. https://doi.org/10.1007/s12665-0090252-9.

Long, A.J., Sawyer, J.F., Putnam, L.D., 2008, Environmental tracers as indicators of karst conduits in groundwater in South Dakota, USA; Hydrogoelogy Journal, v. 16, p. 263-280. https://doi.org/10.1007/s10040-007-0232-7.

Luhmann, A.J., Covington, M.D., Myre, J.M., Perne, M., Jones, S.W., Alexander Jr., E.C., and Saar, M.O., 2015, Thermal damping and retardation in karst conduits: Hydrology and Earth System Sciences, v. 19, p. 137-157. https://doi.org/10.5194/hess-19-137-20015.

Milanović, P.T., 2000, Geological engineering in karst. Zebra, Belgrade, 347 p.

Moore, R.D., 2005, Introduction to salt dilution gauging for streamflow measurement Part III: Slug injection using salt in solution: Streamline Watershed Management Bulletin, v. 8, no. 2, p. 1-6.

Murdock, S.H., and Powell, R.L., 1967, Subterranean drainage routes of Lost River, Orange County, Indiana, in Proceedings, Indiana Academy of Science, v. 77 , p. 250-255.

NOAA Climate Data Online, https://www.ncdc.noaa.gov/cdo-web/, [last accessed on June 28, 2018].

Panno, S. V., Hackley, K.C., Huehwa H. Hwang, and Kelly, W.R., 2001, Determination of the sources of nitrate contamination in karst springs using isotopic and chemical indicators: Chemical Geology, v. 179, p. 113-128. https://doi.org/10.1016/S0009-2541(01)00318-7. 
Panno, S. V., and Kelly, W.R., 2004, Nitrate and herbicide loading in two groundwater basins of Illinois' sinkhole plain: Journal of Hydrology, v. 290, p. 229-242. https://doiorg/10.1016/j.jhydrol.2003.12.017.

Panno, S.V., Krapac, I.G., Weibel, C.P., and Bade, J.D., 1996, Groundwater Contamination in Karst Terrain of Southwestern Illinois: Champaign, Illinois, Illinois State Geological Survey v. 151, p. 43.

Payn, R.A., Gooseff, M.N., McGlynn, B.L., Bencala, K.E., and Wondzell, S.M., 2009, Channel water balance and exchange with subsurface flow along a mountain headwater stream in Montana, United States: Water Resources Research, v. 44, p. W11427. https://doi. org/10.1029/2008WR007644.

Perrey, J.I. and Corbett, D.M., 1956, Hydrology of Indiana Lakes, U.S. Geological Survey, Water Supply Paper 1363,360 p.

Pinsak, A.P., and Shaver, R.H., 1964, The Silurian formations of northern Indiana, Indiana Geological Survey Bulletin, v. 32,87 p.

Powell, J.Z., 1913, History of Cass County Indiana: From its Earliest Settlement to the Present Time; with Biographical Sketches and Reference to Biographies Previously Compiled, Lewis Publishing Company, v. 1, p. 715.

Powell, R.L., 2002, Distribution of sinkholes, sinking-stream basins, and cave openings in southeastern Indiana: Bloomington, Indiana, Indiana Geological Survey.

Pronk, M., Goldscheider, N., and Zopfi, J., 2006, Dynamics and interaction of organic carbon, turdbidity, and bacteria in a karst aquifer system: Hydrogeology Journal, v. 14, p. 473-484. https://doi.org/10.1007/s10040-005-0454-5.

Pyron, M. and Neumann, K., 2008, Hydrologic alterations in the Wabash River Watershed, USA; River Research and Applications, v. 24, p. 1175-1184. https://doi:10.1002/rra.1155.

Randall, G.W., and Mulla, D.J., 2001, Nitrate nitrogen in nurface waters as influenced by climatic conditions and agricultural practices: Journal of Environmental Quality, v. 30, p. 337-344. https://doi.org/ 0.2134/jeq2001.302337x.

Reed, T.M., Fryar, A.E., Brion, G.M., and Ward, J.W., 2011, Differences in pathogen indicators between proximal urban and rural karst springs, Central Kentucky, USA: Environmental Earth Sciences, v. 64, p. 47-55. https://doi.org/10.1007/s12665-010-0816-8.

Runkel, A.C., Steenberg J.R., Tipping R.G., Retzler A.J., 2013, Physical hydrogeology of the groundwater-surface water system of southeastern Minnesota and geologic controls on nitrate transport and stream baseflow concentrations: Minnesota Geological Survey report delivered to the Minnesota Pollution Control Agency, Contract number B50858 (PRJ07522).

Ryan, M., and Meiman, J., 1996, An examination of short-term variations in water quality at a karst spring in Kentucky: Ground Water, v. 34 , no. 1, p. 23-30. https://doi.org/10.1111/j.1745-6584.1996.tb01861.x.

Sasowsky, I.D., Dinsmore, M.A., Salvati, R., Bixby, R., Raymond, H., and Mazzeo, P., 2003, Subtle but significant karst on the glaciated Bellevue-Castalia karst plain, Ohio, USA, in Ninth Multidisciplinary Conference on Sinkholes and the Engineering and Envionmental Impacts of Karst, Huntville, Alabama, p. 95-109. https://doi.org/10.1061/40698(2003)8.

Sinkhole Areas and Sinking-Stream Basins (1997), Indiana Geological and Water Survey, Indiana University, http://maps.indiana.edu/previewMaps/Hydrology/Karst Sinkhole_Areas.html, [last accessed on June 28, 2018].

Smart, C.C. and Ford, D.C., 1982, Quantitative dye tracing in a glacierized alpine karst: Beit. Geol. Schweiz. Hydrol., v. 28, no. 1, p. $191-200$.

Smart, C.C., 1988, Artificial tracer techniques for the determination of the structure of conduit aquifers: Ground Water, v. 26, p. 445-453. https:// doi.org/10.1111/j.1745-6584.1988.tb00411.x.

Torres, M.C. and Bair, E.S., 2012, Paleokarst in central and northwest Ohio: The Newburg Zone as a system of Silurian flank margin caves: Geological Society of America Abstracts with Programs, v. 44, no. 5, p. 3.

Upchurch, S.B., Dobecki, T.L., Scott, T.M., Meiggs, S.H., Fratesi, S.E., and Alfieri, M.C., 2013, Development of sinkholes in a thickly covered karst terrane, in Land, L., Doctor, D.H., and Stephenson, J.B., eds., Sinkholes and the Engineering and Environmental Impacts of Karst: Proceedings of the Thirteenth Multidisciplinary Conference, May 6-10, Carlsbad, New Mexico: NCKRI Symposium 2. Carlsbad (NM), National Cave and Karst Research Institute, 497 p.

Veress, M., 2016, Covered Karsts: Dordrecht, Springer, 536 p.

Wabash Formation: Niagaran and Cayugan Series, Silurian System; Indiana Geological and Water Survey, Indiana University, https://igs.indiana. edu/compendium/comp8qlg.cfm [last accessed on June 28, 2018.

Wanfang Zhou, Beck, B.F., Pettit, A.J., and Stephenson, B.J., 2002, A groundwater tracing investigation as an aid of locating groundwater monitoring stations on the Mitchell Plain of southern Indiana: Environmental Geology, v. 41, p. 842-851. https://doi.org/10.1007/s00254-001-04640 .

Wanfang Zhou, and Beck, B.F., 2008, Management and mitigation of sinkholes on karst lands: An overview of practical applications: Environmental Geology, v. 55, no. 4, p. 837-851. https://doi.org/10.1007/s00254-007-1035-9.

Wayne, W.J., Johnson, G.H., and Keller, S.J., (1966), Geologic map of the 1 degree $\times 2$ degree Danville quadrangle, Indiana and Illinois, showing bedrock and unconsolidated deposits [Part A -bedrock units only: Regional Geologic Map No. 2, Indiana Geological Survey, Bloomington, Indiana.

Wiersma, J.H., Stieglitz, R.D., Cecil, D.L., and Metzler, G.M., 1986, Characterization of the shallow groundwater system in an area with thin soils and sinkholes: Environ. Geol. Water Sci., v. 8, no. 1/2, p. 99-104. https://doi.org/10.1007/BF02525563.

Wilson, J.L. and Henry, K., 2013, Karst conduit sinuosity as a driver of karst hyporheic exchange, Abstract \# EP12A-07, American Geophysical Union, Fall Meeting.

Zötl, J., 1989, Paleokarst as an important hydrogeological factor, in Bosák, P., Ford, D.C., Glazek, J., and Horáček, eds., Paleokarst: A Systematic and Regional Review, , Elsevier and Academia, Amsterdam and Praha, $726 \mathrm{p}$. 